Discussion Paper No. 15-024

\title{
Aging and Urban House Prices
}

Norbert Hiller and Oliver W. Lerbs

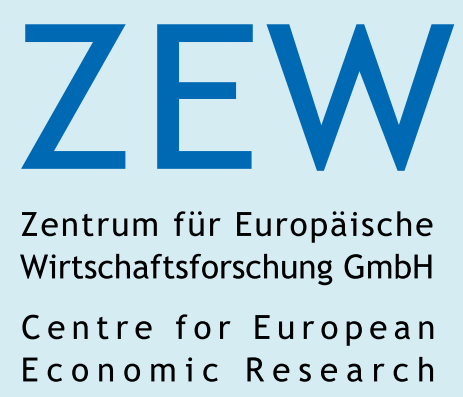


Discussion Paper No. 15-024

\title{
Aging and Urban House Prices
}

\author{
Norbert Hiller and Oliver W. Lerbs
}

Download this ZEW Discussion Paper from our ftp server:

http://ftp.zew.de/pub/zew-docs/dp/dp15024.pdf

Die Discussion Papers dienen einer möglichst schnellen Verbreitung von neueren Forschungsarbeiten des ZEW. Die Beiträge liegen in alleiniger Verantwortung der Autoren und stellen nicht notwendigerweise die Meinung des ZEW dar.

Discussion Papers are intended to make results of ZEW research promptly available to other economists in order to encourage discussion and suggestions for revisions. The authors are solely responsible for the contents which do not necessarily represent the opinion of the ZEW. 


\title{
Aging and Urban House Prices
}

\author{
Norbert Hiller ${ }^{a^{*}}$, Oliver W. Lerbs ${ }^{\mathrm{b} \dagger}$ \\ ${ }^{a}$ University of Münster \\ ${ }^{\mathrm{b}}$ Centre for European Economic Research (ZEW), Mannheim
}

\begin{abstract}
This paper investigates the long-run relationships between the size and age composition of a city's population and the price of local housing. For estimation purposes, we combine city-level demographic information with housing price data for 87 cities in Germany over the period 1995-2012. Employing a panel error correction framework that accounts for the evolution of city income and other controls, we find that urban house prices perform stronger in cities that grow or age less rapidly. A combination of the empirical estimates with current population projections suggests that population aging will exert considerable downward pressure on urban house prices in upcoming years.
\end{abstract}

Keywords: Urban house prices · demographic change · Germany

JEL classification: G12 · J11 $\cdot$ R31

\footnotetext{
* Correspondence: Institute for Spatial and Housing Economics, University of Münster, Phone: 0251-8322432, E-Mail: hiller@insiwo.de.

† Correspondence: Centre for European Economic Research (ZEW), Research Department of International Finance and Financial Management, Phone: 0621-1235-147, E-Mail: lerbs@zew.de.
} 


\section{Introduction}

Housing is a dominant asset in the household portfolio of owners. At the same time, a considerable proportion of housing capital in modern economies is concentrated in urban areas. ${ }^{1}$ Wealth formation in the private sector is therefore closely associated with the evolution of housing prices in the very same locations that lie at the heart of economic activity (Rosenthal and Strange 2004). Since a substantial part of housing capital is debt-financed, unforeseen city house price developments can threaten household net wealth and financial stability (Mian and Sufi 2009). The systemic relevance of urban house prices is further amplified by evidence that real house price changes in cities tend to ripple out towards geographically adjacent regions (Meen 1999, Lee and Chien 2011).

The aim of this paper is to empirically examine the hypothesis of a long-term equilibrium relationship between urban house prices and the age structure and size of cities. The housing market effects of demographic change have been a vital area of research since the seminal paper of Mankiw and Weil (1989). Eichholtz and Lindenthal (2014) recently provide microeconometric evidence that individual housing demand depends heavily on demography and education. This supports earlier studies such as Green and Hendershott (1996) or Ermisch (1996). Recent studies based on macro data also suggest strong empirical links between housing prices and demography at both the national and regional level. Takáts (2012) finds that real house price growth in OECD countries over 1970-2009 was promoted by population growth, but depressed by an aging population, ceteris paribus. ${ }^{2}$ Saita et al. (2013) confirm these interrelated findings, based on data for Japanese prefectures and US states over 1976-2010 and 1975-2011, respectively. Their results suggest even stronger house price effects of demography. Especially for Japanese prefectures, the coefficients estimated on the age structure are larger, while those estimated on total population are comparable to those found by Takáts.

Given that housing markets are local by nature, there is a striking paucity of studies investigating the long-term housing price effects of demography using city data. ${ }^{3}$ One

\footnotetext{
1 The term "urban area" usually extends to cities, towns as well as larger conurbations. In this paper, we refer to 87 German urban areas defined as administratively independent cities.

2 Takáts' favorite specification suggests the elasticity of real house prices with respect to total population size to be 1.05, while the elasticity with respect to age structure (old age dependency ratio) is -0.68 . According to these findings, the major directional shift in demographic change in the upcoming four decades is expected to decrease real OECD house prices by around 80 basis points per annum.

${ }^{3}$ Research based on local housing market data has concentrated on the short-run, cyclical behavior of metropolitan housing prices. Some studies focus on transitory metropolitan house price bubbles (Gallin 2008, Goodman and Thibodeau 2008, Glaeser et al. 2008). Others focus on the time series properties of city-level house price data (Capozza et al. 2002, Miller and Peng 2006). Another line of papers has concentrated on heterogeneity with regard to the reactions of city-level house prices to a monetary stimulus or shocks to aggregate macroeconomic variables (Himmelberg et al. 2005, Carlino and DeFina 2008). Yet
} 
of the few exceptions is Maennig and Dust (2008), who study the quantitative relationship between the 1992-2002 percentage change in population and single-family house price levels in 98 German cities in 2002. Their analysis suggests no statistically significant relationship between house prices and past population increases, whereas a decline in population between 1992 and 2002 is associated with significantly lower 2002 price levels. Since their analysis draws on cross-sectional price information only, they could neither assess the long-term effects of gradual changes in population size, nor the longterm effects of gradual shifts in a city's age structure on local housing prices.

We add to the existing literature with two main contributions. First, we estimate long-run cointegration relationships between the main variables of interest in a city panel error correction framework. For this purpose, we combine demographic information with housing price data for 87 German cities over the period 1995-2012. In using German data, we can exploit an exceptionally large variation in demographic developments across local housing markets that help identifying their long-term price effects. Based on a combination of our econometric estimates with population forecasts by official sources, we secondly provide probabilistic projections of demography-induced price effects for each city until 2020. Projections are conditional on non-demographic variables remaining constant. The availability of detailed local demographic projections by official sources is another key advantage of using German data.

Prior to estimating a reasonable econometric model, we argue theoretically that along with changes in the number of households who demand housing services, changes in the age structure of cities can substantially alter the demand for local housing services and housing capital. We point out that long-term housing price reactions to these demand changes depend on housing supply elasticity, which is implicitly reflected in our empirical estimates. Our econometric results support the hypothesis that the development of a city's size and age structure over time is a fundamental determinant of long-run real house price evolution. The probabilistic projections of future price trajectories demonstrate that housing equity in many German cities is likely to face considerable headwind from population aging in upcoming years. We argue that this result is transferable to other countries with similar demographic prospects.

The remainder of this paper is organized as follows. Section 2 reviews theoretical hypotheses regarding the effects of urban demography on house prices. Section 3 introduces the data set, discusses the panel stationarity properties of the data, and presents key facts regarding past and expected future demographic developments in Germany. Section 4 considers the econometric framework, presents the econometric results and discusses probabilistic projections of future urban house prices. Section 5 concludes with policy implications. 


\section{Theory of urban demography and house prices}

Economic theory suggests at least three distinct channels through which gradual changes in the total size and age composition of a city's resident population affect local house prices. The first channel is the effect of these demographic variables on the demand for housing services. Along with incomes and preferences, the total number of households residing in a city determines total demand for flows of housing services, which in turn determines real house prices in interaction with available housing supply (DiPasquale and Wheaton 1994). A change in average house prices due to a shift in total household population can be labelled the size effect. In addition to the size effect, household demand for housing services underlies a life cycle (Pitkin and Myers 1994, Flavin and Yamashita 2002). Housing services demand is comparatively low during schooling years, increases with labor market entry, peaks with starting and maintaining a family and decreases again in retirement. ${ }^{4}$ This can be labelled the age effect. Assuming that the long-run city housing supply schedule is finitely elastic, the size effect suggests that if the total number of households in a city increases, so do house prices. The age effect suggests that real house prices decrease if the number of retirement age relative to working age individuals, in a city shifts upward.

A second channel refers to the investment demand for owner-occupied housing as a durable asset. Young households purchase urban housing capital as a conduit of saving and retirement provision and dissolve (parts of) their housing assets to move to peripheral locations or to rent again in retirement (Henderson and Ioannides 1983, Kraft and Munk 2011). An upward shift in the number of retirement age individuals relative to working age individuals in a city thus implies a lower demand for investments in urban owner-occupied housing. Again, the long-run price effects of this change to demand depend on the price elasticity of housing supply. Different from housing services demand, the effects of aging on investment demand and prices are intrinsically selfreinforcing. That is, forward-looking home buyers most likely anticipate future price declines caused by forthcoming increases in the ratio of sellers to buyers in the market. Since lower expected real house price gains raise housing capital costs, this decreases housing investment demand and prices today.

A third, more subtle effect concerns the supply side of urban housing markets. Local demography is unlikely to affect local construction costs, given that construction workers, as well as other mobile inputs, can be hired from elsewhere. An essential production factor that may however be affected by demography is the amount of land that is made available for new local construction. Anticipating population decline and aging, city planners may opt for tighter zoning to stabilize prices in the existing stock. Anoth-

\footnotetext{
${ }^{4}$ In the presence of borrowing constraints and other frictions, households face obstacles in smoothing housing services consumption over the life cycle and will thus tend to purchase self-owned housing (which often requires a down payment and high levels of creditworthiness) in later stages in life.
} 
er possibility is to remove excess housing through demolition. Both options were realized at considerable scale in eastern German cities since reunification (Bernt 2009).

Since we are interested in the long-term price effects of shifts to local demography, our identification strategy relies on the assumption that city-level housing supply is finitely elastic and price elasticity itself can be affected by local demography. The partial elasticities of real urban house prices with respect to key demographic variables then reflect the joint effect of these fundamentals on the demand for housing services, the investment demand for housing capital, and the local land market.

Based on the prior theoretical considerations, we define our baseline regression model as follows:

$P_{i t}=\beta_{0}+\beta_{1} H_{H P O P}+\beta_{2} O A D R_{i t}+\beta_{3} I N C_{i t}+\beta_{4} H C R_{i t}+\beta_{5} I N T_{t}+\mu_{i}+\varepsilon_{i t}$

where $P_{i t}$ is real house price in city $i$ at time period $t, H H P O P_{i t}$ is total household population, $O A D R_{i t}$ is the proportion of retirement age to working age residents (the old age dependency ratio) and $I N C_{i t}$ is real average income per capita. In view of recent empirical evidence that individual education is another key determinant of housing services demand at the household level, we additionally include the number of city workers with college degrees relative to those without any formal educational degree, which we refer to as the city's human capital ratio $\left(H C R_{i t}\right)$. To account for changes in housing financing costs over time, $I N T_{t}$ indicates the national mortgage interest rate in year $t$. The $\mu_{i}$ represent unobserved city-level effects, while $\varepsilon_{i t}$ is a disturbance term with usual properties. We evaluate the empirical evidence in favor or against the accuracy of predictions based on theory relying on the statistical significance and economic relevance of $\beta_{1}$ and $\beta_{2}$.

\section{Data}

\subsection{Data set}

Our econometric analysis relies on a panel data set with 87 German cities on its crosssectional dimension and 18 years (1995-2012) on its time period dimension. In the literature, such data sets are commonly termed macro panels or time series panels. Panels characterized by moderate group sizes and substantial time periods are often distinguished by panel heterogeneity and non-stationarity in the individual time series (Banerjee 1999, Phillips and Moon 2000). Such data sets offer econometric opportunities that differ to a large degree from micro panels. Most notably, they enable flexible dealing with dynamics and the identification of long-term equilibrium relationships (Eberhardt and Teal 2011). However, the majority of empirical research based on time series panels still implements micro panel methods. ${ }^{5}$ In urban and regional economics, the analysis of non-stationary time series panels with appropriate methods is still

\footnotetext{
${ }^{5}$ Time series panel data sets and the respective methods are traditionally more common in country-level analysis.
} 
scarce. Apergis et al. (2010) investigate the regional relationship between corruption and income. Beenstock and Felsenstein (2010) and Holly et al. (2010) are two examples of analyzing regional house prices.

Table 1 reports our variable definitions and data sources. As a representative measure of urban house prices, we use assessed typical repeat sales prices of owner-occupied apartments of medium size, quality and location. ${ }^{6}$ The price information relies on standardized annual surveys among local brokers, appraisers and surveyors and is provided by the private consulting firm Bulwien Gesa. The same data is used for housing market analysis by the German Bundesbank (Kajuth et al. 2013) and is widely respected as a valid indicator of spatially disaggregated house prices. ${ }^{7}$ The real house price in city $i$ at time period $t$ is defined as the average price in EUR per square meter, corrected for consumer price inflation in the same period.

Table 1. Variable definitions and sources

\begin{tabular}{|c|c|c|}
\hline Variable & Definition & Source \\
\hline Real house price & Real resale apartment price in EUR per sqm & BulwienGesa \\
\hline Total household population & Number of resident households in a city & $\begin{array}{l}\text { German Federal Institute for Research } \\
\text { on Building, Urban Affairs and Spatial } \\
\text { Development }\end{array}$ \\
\hline Old age dependency ratio & $\begin{array}{l}\text { Ratio of retirement age ( } 65 \text { years or older) to } \\
\text { working age (20-64 years) residents }\end{array}$ & German Regional Statistical Office \\
\hline Real income per capita & Real GDP divided by number of employees & $\begin{array}{l}\text { German Federal Statistical Office (GDP) } \\
\text { and German Federal Institute for } \\
\text { Research on Building, Urban Affairs and } \\
\text { Spatial Development (employees) }\end{array}$ \\
\hline Human capital ratio & $\begin{array}{l}\text { Ratio of workers with college degree to } \\
\text { workers without formal educational degree }\end{array}$ & German Federal Employment Office \\
\hline Real mortgage interest rate & $\begin{array}{l}\text { Average effective real interest on building } \\
\text { society mortgages }\end{array}$ & German Bundesbank \\
\hline
\end{tabular}

As a measure of the local demand for housing services, we calculate annual city-level household populations, combining time series on population obtained from the German

\footnotetext{
${ }^{6}$ Owner-occupied apartments can be considered as a specific type of housing in which urban households in Germany are invested. In comparison to single-family or two-family houses, which are typically prevalent in urban surroundings or more peripheral locations, owner-occupied apartments are typically located in multi-family houses in central urban locations. If defined as the proportion of all residential dwellings that are occupied by their owners, the German home ownership rate is 42.6 per cent (2011 Census). This corresponds to 17.3 million owner-occupied dwellings. 3.5 million, or 20 per cent of all 17.3 million owner-occupied dwellings, are located in city-dominating multi-family buildings.

${ }^{7}$ The national home price index published by the Federal Statistical Office is derived from disaggregated data reported by public local boards of surveyors (Lokale Gutachterausschüsse).
} 
Federal Statistical Office with information on average local household size from the Federal Institute for Research on Building, Urban Affairs and Spatial Development (Bundesinstitut für Bau-, Stadt- und Raumforschung, BBSR). As a measure of a city's age structure, we compute the old age dependency ratio as the proportion of retirement age (65 years or older) to working age (20-64 years) residents. ${ }^{8}$ As a measure of local purchasing power, we define annual real city income as the total production in city $i$ in year $t$, corrected for CPI inflation in the same period, divided by the total number of employees in the same year. As a measure of urban education, we define the human capital ratio as the proportion of high-qualification jobs (workers with a college degree) to low-qualified jobs (workers without any formal labor market qualification) in the city, using information from the German Federal Employment Office. As a measure of the real private housing financing cost at the national level, we use the CPI inflationcorrected effective interest rate on building society mortgages. Interest rate and CPI inflation data are obtained from the German Bundesbank.

Figure 1 illustrates the geographic locations of the 87 cities in the data set. According to the 2011 Census, the cities encompass 30.5 per cent of the German population and 33.2 per cent of all households. Table A1 in the Appendix lists mean values and standard deviations of all variables for each city in the sample over the sample period.

Figure 1. Geographic locations of all 87 cities in the sample

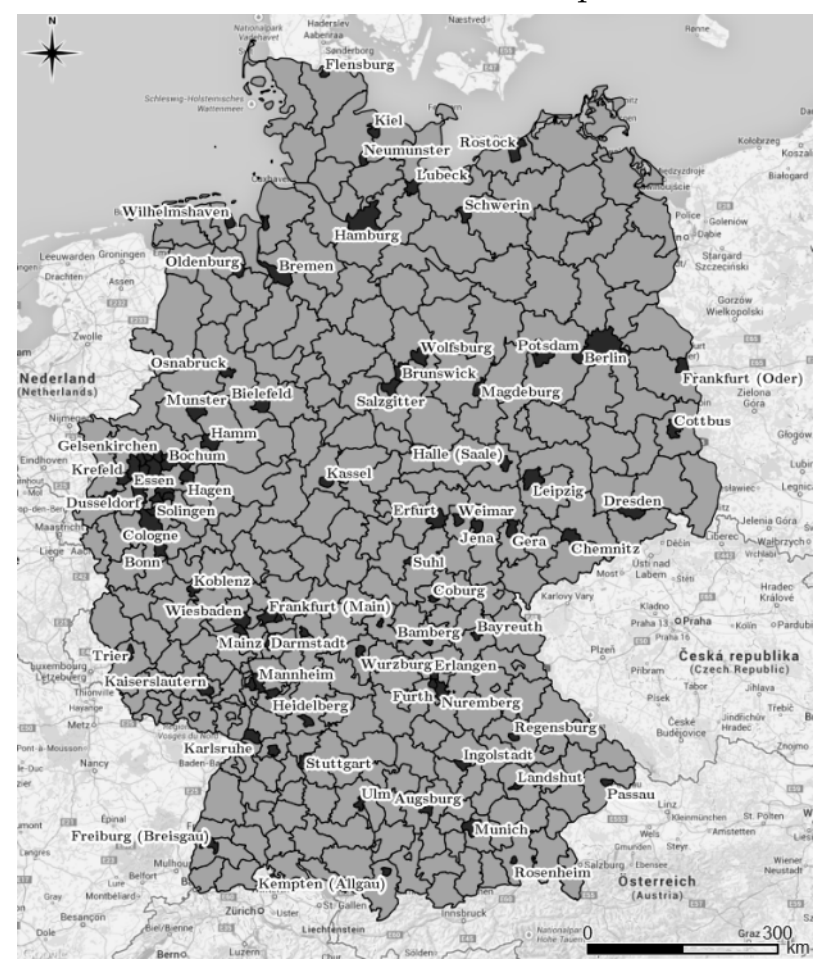

Source: Authors' own depiction using Google Maps.

\footnotetext{
${ }^{8}$ Compared to other statistics related to the age distribution of the resident population, such as the median age or skewness measures, the old age dependency ratio is both an economically plausible and a compact measure of urban demography. We expect changes in the urban old age dependency ratio over time to capture the underlying economic problem of gradual shifts in the relative proportion of suppliers and demanders in the urban housing market.
} 


\subsection{National and city-wide demographic trends in Germany}

Like other industrial economies such as the US or Japan, Germany will be severely affected by demographic change in upcoming decades. According to the most recent population projection by the German Federal Statistical Office, Germany's total population will decline by between 14 and 20 per cent by 2060, based on 81 million in 2012 (Destatis 2009). ${ }^{9}$ The main cause is Germany's low total fertility rate. Importantly, inward migration may reduce the expected decline in population, but most likely will not stop it. Using data from the "medium variant" projection, Figure 2 shows that even under the optimistic assumption of a net migration balance of $+200,000$ annually, total population will decrease by about 1 million inhabitants between 2012 (the end year of our sample period) and 2030. For sake of transparency, the projection period for our own house price forecasts in shaded in light grey.

Figure 2. Total population in Germany by 2030

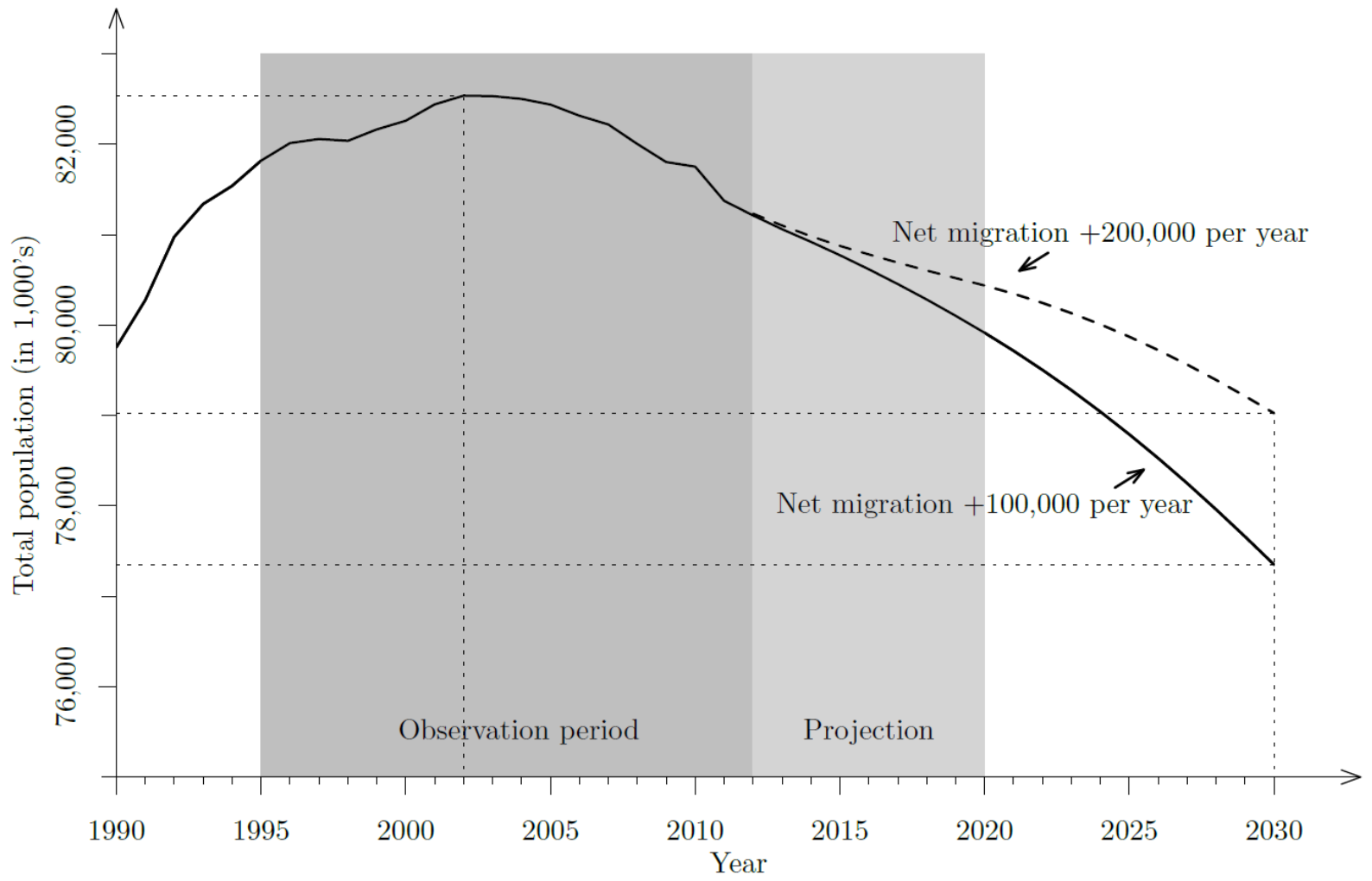

Source: German Federal Statistical Office, 12 $2^{\text {th }}$ Coordinated Population Projection, Var. 1-W1/2

In addition to overall decline, the German population's age profile will undergo substantial change. Due to the low fertility rate and a longer life expectancy, the share of elderly in the population is expected to increase considerably. We illustrate aging in Figure 3 by displaying the past and projected temporal evolution of the nationwide old age dependency ratio, again using information from the most common population forecast scenario of the German Federal Statistical Office. According to this scenario, Ger-

\footnotetext{
${ }^{9}$ Projections of household numbers are also available for the nation, but we prefer to rely on population figures to depict demographic trends at the national level.
} 
many's nationwide old age dependency ratio will increase from 0.35 in 2012 to over 0.5 in 2030, showing very little sensitivity to net migration. This development is quite noteworthy: compared to the projected decrease in total population of 1.5-3 per cent over the same time horizon, the scenario implies an upward shift in the old age dependency ratio of more than 40 per cent over 2012-2030.

Figure 3. Old age dependency ratio in Germany, 1990-2030

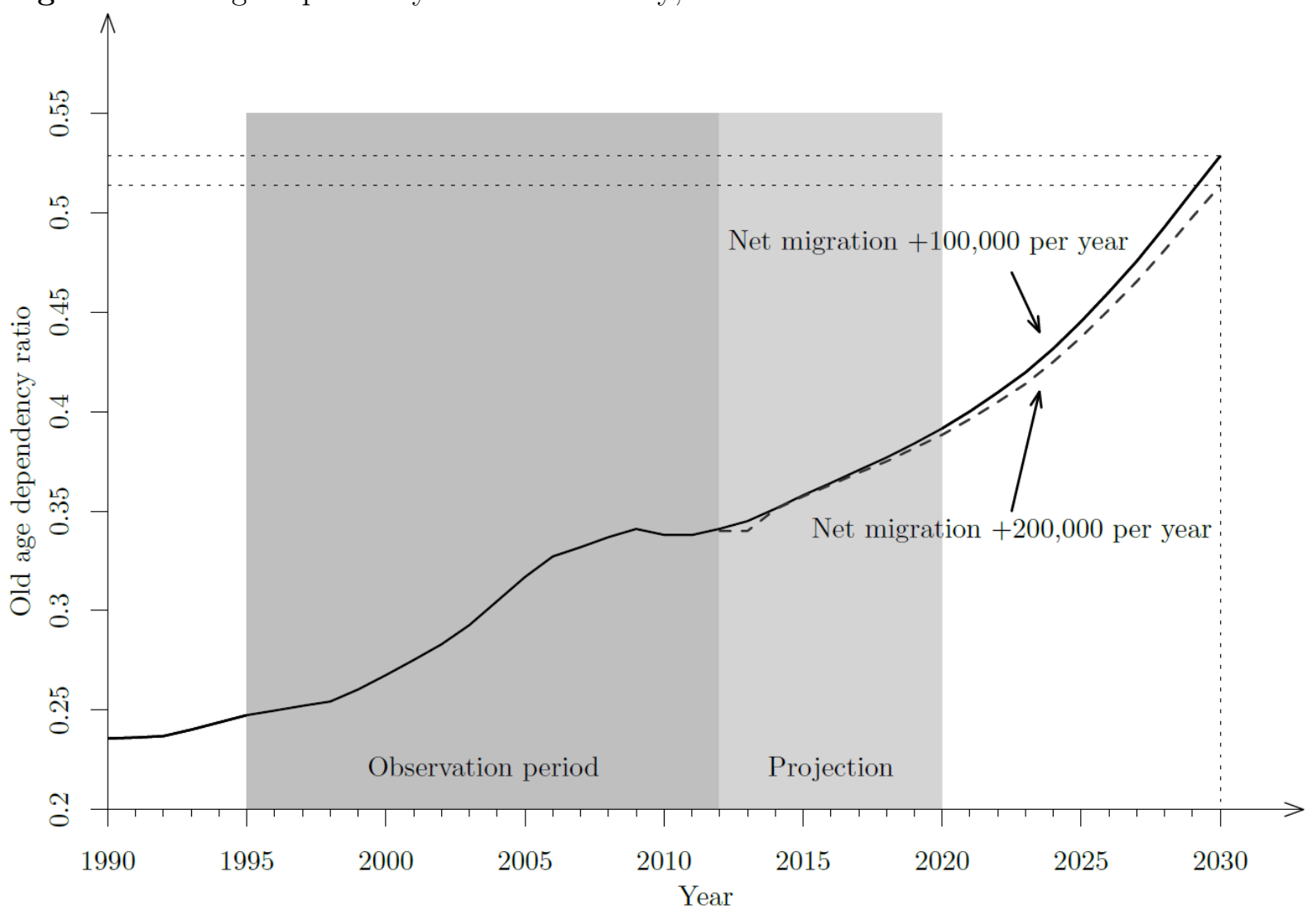

Source: German Federal Statistical Office, 12 ${ }^{\text {th }}$ Coordinated Population Projection, Var. 1-W1/2.

A distinct feature of demographic change is its high spatial diversity. Our data reveal that cross-sectional variation in the temporal development of household population figures and old age dependency ratios across German cities over the sample period 1995-2012 was indeed substantial. Figure 4 displays six different characteristic cases illustrating this variation. Tentatively, a more positive demographic development appears to be associated with better performing urban house prices. For example, in $\mathrm{Mu}$ nich, Bavaria (upper left panel), total household population displayed a continuous increase over 1995-2012, while the old age dependency ratio was low and almost remained constant. Real house prices in this city displayed a positive trend. The Saxon city of Chemnitz (lower right panel) is an example of exactly contrary developments. Household population declined from 0.138 to 0.132 million over 1995-2012, while the old age dependency ratio increased substantially from 0.28 to 0.45 (a relative increase of 60 per cent). At the same time, real house prices declined by more than 50 per cent. The other four examples display cities that range between these two extreme cases. 
Figure 4. Six examples of city-wide house price, population and old age dependency ratio evolutions, 1995-2012
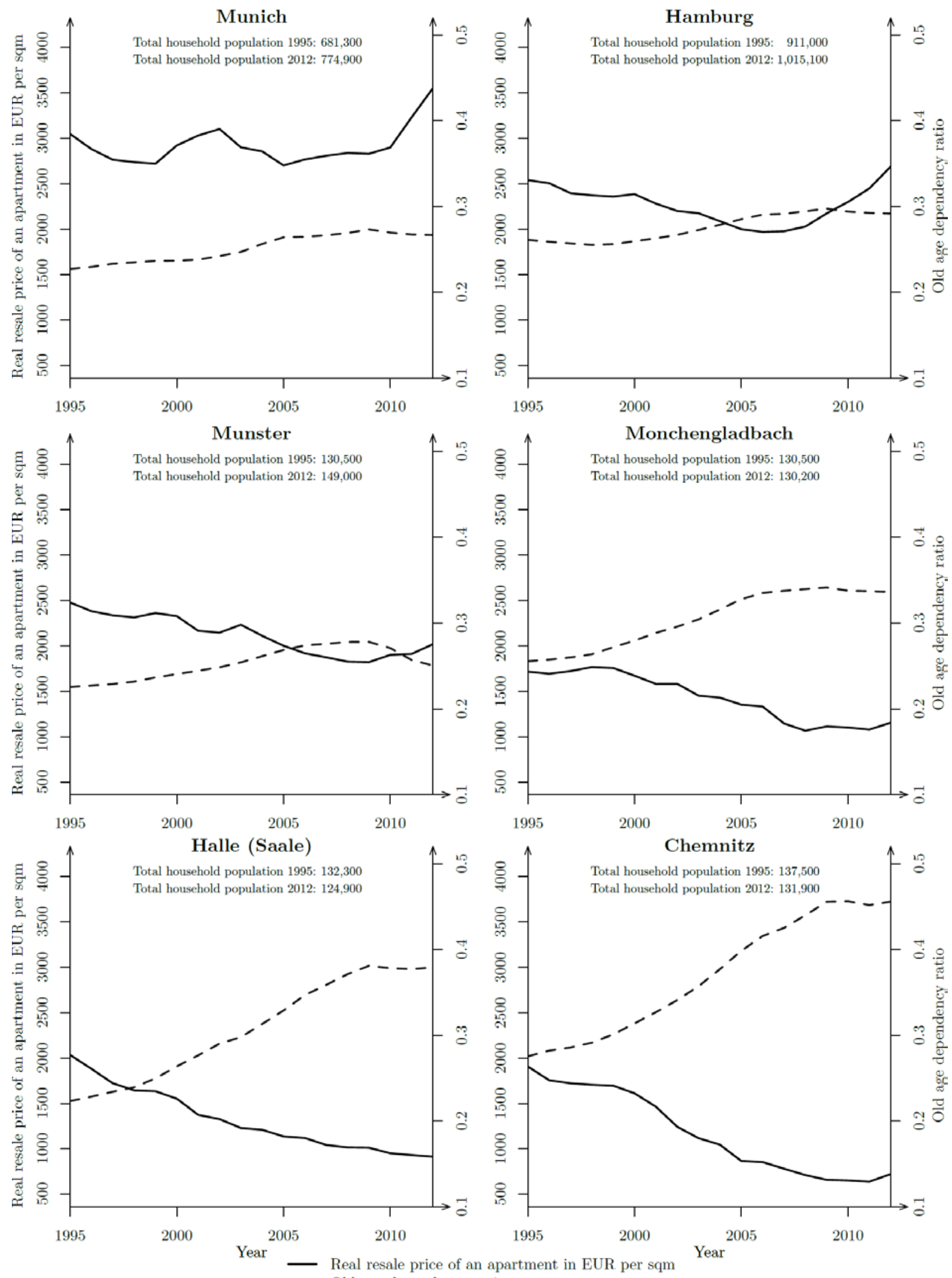

- - Old age dependency ratio

Sources: BulwienGesa, German Federal Statistical Office, authors' own calculations. 


\section{Empirical methodology and results}

We first analyze the stationarity properties of our data set with established panel stationarity and panel cointegration tests. We then estimate a panel error correction model (PECM) based on the work of Pesaran and Smith (1995) and Pesaran et al. (1999). The time dimension of our panel data is not large enough for reliable inference on the cointegration parameters in each time series separately. However, annual observations of 18 years enable the measurement of long-run house price elasticities of our variables of interest, based on restrictions on heterogeneity in the cointegration relationships. We exploit the cross-section information of the panel data by group pooling, based on the notion of strong commonalities across the 87 cities in our sample. Specifically, we assume common long-run cointegration relationships between housing prices and our main explanatory variables among all cities, but allow for heterogeneity across groups in short-run dynamics (Pesaran et al. 1999).

\subsection{Panel unit root and cointegration tests}

Inference techniques for unit root testing in panel data encompass a substantial body of literature (Harris and Tzavalis 1999, Choi 2001, Levin et al. 2002, Im et al. 2003). Panel unit root tests are based on a first-order autoregressive model allowing for two-way unobserved effects and time trends:

$\Delta y_{i t}=\alpha_{i}+\theta_{t}+\delta t+\varrho_{i} y_{i, t-1}+\varepsilon_{i t}$

where $y_{i t}$ is the variable of interest, $\alpha_{i}$ and $\theta_{t}$ represents group and time fixed effects, $\delta_{t}$ is a deterministic time trend, and $\varepsilon_{i t}$ is a normally distributed error term. Depending on whether the specific test assumes homogeneity or heterogeneity in the autoregressive parameter, the tests involve the null hypothesis that all panels are integrated of order 1, versus the alternative that either all or a fraction of the panels form stationary series.

We employ different types of tests for the hypothesis of stationarity of our panel data. The Levin-Lin-Chu (LLC) test can be viewed as a pooled Augmented Dickey Fuller test as it assumes that all panels have the same autoregressive parameter, $\varrho_{i}=\varrho$. In the absence of a deterministic term, the test allows the number of time periods to tend to infinity at a slower rate than the number of cross-sectional units, though $T$ must go to infinity sufficiently fast to secure that $\lim _{N, T \rightarrow \infty} \sqrt{N} / T=0$. The Harris-Tzavalis (HT) test also assumes homogeneity in the autoregressive parameter, but different from the LLC test, the number of time periods is fixed (Harris and Tzavalis 1999). The ImPesaran-Shin (IPS) test allows each group to have its own autoregressive parameter $\varrho_{i}$ instead of a common $\varrho$ (Im et al. 2003). The IPS statistics assume the number of time periods is fixed, while $\mathrm{N}$ tends to infinity.

All three tests are first applied to the natural logarithms of real city house prices, total household population, old age dependency ratios, income per capita, human capi- 
tal ratios, and the real mortgage interest rate at their respective levels. The respective tests are then applied to the first differenced panel series of each variable in logs. For both cases, all tests are performed with and without the inclusion of a deterministic time trend. Appropriate lag lengths are chosen based on the Akaike Information Criterion.

The upper part of Table 2 reports the test results for the non-differenced variables. Except for the LLC test, the null hypothesis of non-stationarity cannot be rejected in most cases, which indicates that at least some variables are I(1). A first-difference transformation of the data is needed to generate a stationary time series (Hamilton 1994). The lower part of Table 2 lists the test results after this transformation. The null hypothesis of non-stationarity has to be rejected at common significance levels for each variable throughout, except for the old age dependency ratio, where rejection is possible only in two of six cases.

Table 2. Panel unit root tests

\begin{tabular}{|c|c|c|c|c|c|c|}
\hline \multirow[t]{3}{*}{ Variables } & \multicolumn{2}{|c|}{ Levin-Lin-Chu } & \multicolumn{2}{|c|}{ Im-Pesaran-Shin } & \multicolumn{2}{|c|}{ Harris-Tzavalis } \\
\hline & \multicolumn{2}{|c|}{$\begin{array}{c}\mathrm{H}_{0}: \varrho_{i}=\varrho \text { for all } \mathrm{i} \\
\mathrm{H}_{\mathrm{a}}: \varrho<1 \\
\mathrm{~T} \rightarrow \infty, \mathrm{N} \rightarrow \infty\end{array}$} & \multicolumn{2}{|c|}{$\begin{array}{c}\mathrm{H}_{0}: \varrho_{i}=1 \text { for all } \mathrm{i} \\
\mathrm{H}_{\mathrm{a}}: \varrho_{i}<1 \\
\mathrm{~T} \text { is fixed, } \mathrm{N} \text { is fixed }\end{array}$} & \multicolumn{2}{|c|}{$\begin{array}{c}\mathrm{H}_{0}: \varrho=1 \\
\mathrm{H}_{\mathrm{a}}: \varrho<1 \\
\mathrm{~T} \text { is fixed, } \mathrm{N} \rightarrow \infty\end{array}$} \\
\hline & $\begin{array}{c}\text { No trend } \\
\text { Test statistic }\end{array}$ & $\begin{array}{c}\text { Trend } \\
\text { Test statistic }\end{array}$ & $\begin{array}{c}\text { No trend } \\
\text { Test statistic }\end{array}$ & $\begin{array}{c}\text { Trend } \\
\text { Test statistic } \\
\end{array}$ & $\begin{array}{c}\text { No trend } \\
\text { Test statistic }\end{array}$ & $\begin{array}{c}\text { Trend } \\
\text { Test statistic }\end{array}$ \\
\hline \multicolumn{7}{|l|}{ Levels } \\
\hline Log real house price & $-8.3540 * * *$ & 8.7452 & -0.3307 & 12.3455 & 0.9161 & 0.8657 \\
\hline Log total houshold population & $-3.3291 * * *$ & $-12.7289 * * *$ & 5.6639 & $-4.6835 * * *$ & 0.9961 & 0.7435 \\
\hline Log old age dependency ratio & $-15.0019 * * *$ & 8.4740 & $-3.7428 * * *$ & 7.6103 & 0.9504 & 1.0678 \\
\hline Log income per capita & $-3.2574 * * *$ & $-8.9903 * * *$ & -1.0221 & $-4.1044 * * *$ & $0.7572 * * *$ & $0.4479 * * *$ \\
\hline Log real mortgage interest rate & 13.8687 & 5.5116 & 15.3328 & $-2.7545 * * *$ & 1.0092 & $0.3228 * * *$ \\
\hline Log human capital ratio & 3.9977 & $-8.2448 * * *$ & 15.4250 & $-1.3790 *$ & 0.9893 & 0.7537 \\
\hline \multicolumn{7}{|l|}{ Differences } \\
\hline$\Delta \log$ real house price & $-1.3665 *$ & $-5.6437 * * *$ & $-3.0969 * * *$ & $-1.7243 * *$ & $0.2181 * * *$ & $0.2751 * * *$ \\
\hline$\Delta \log$ total houshold population & $-11.6081 * * *$ & $-9.0037 * * *$ & $-8.0989 * * *$ & $-1.4385 *$ & $0.2296 * * *$ & $0.4934 * * *$ \\
\hline$\triangle \log$ old age dependency ratio & 1.7083 & $-8.9246 * * *$ & 3.0505 & 3.9729 & $0.7646 * * *$ & 0.8355 \\
\hline$\triangle \log$ real GDP per employee & $-21.6622 * * *$ & $-19.0850 * * *$ & $-19.9770 * * *$ & $-15.2730 * * *$ & $-0.1721 * * *$ & $-0.1173 * * *$ \\
\hline$\Delta \log$ real mortgage interest rate & $-5.3395 * * *$ & $-5.5048 * * *$ & $-8.7086 * * *$ & $-3.2233 * * *$ & $-0.0667 * * *$ & $-0.0667 * * *$ \\
\hline$\Delta \log$ human capital ratio & $-15.7860 * * *$ & $-18.2613 * * *$ & $-17.2327 * * *$ & $-15.8501 * * *$ & $0.0334 * * *$ & $0.1328 * * *$ \\
\hline
\end{tabular}

$(*, * *, * * *$ denote statistical significance at the $10 \%-, 5 \%$ - and $1 \%$-level, respectively)

If a long-run equilibrium relationship exists between two or more I(1) variables, such that the residuals of a regression of the first variable in levels on a linear combination of the other variables in levels are $\mathrm{I}(0)$, then these variables are said to be cointegrated (Engle and Granger 1987). In order to identify cointegration relationships in a panel context, Kao (1999) and Pedroni (1999, 2004) provide residual-based tests. The Kao Augmented Dickey Fuller test (Kao 1999) assumes that the cointegration relationship in each group is homogenous, whereas the test proposed by Pedroni $(1999,2004)$ allows for heterogeneity in the cointegrating vector. We generate the required residuals based on the theoretically motivated regression relationship presented in Section 2, which 
explains urban real house prices by means of a linear combination of household numbers, age structure, income per capita, the human capital ratio and national financing costs. In addition, we combine the variables to four different specifications. In order to account for potential sensitivity of the cointegration tests with respect to these different specifications, we use different combinations of the explanatory variables (Table 3 ). The Kao ADF test, the Pedroni panel and Pedroni group tests suggest a cointegration relationship between the variables of interest, which is identical among cities in most cases. ${ }^{10}$ There is thus supportive evidence that the variables of interest tend towards long-run equilibrium.

Table 3. Panel cointegration tests

\begin{tabular}{|c|c|c|c|c|}
\hline \multirow[b]{2}{*}{ Variables } & \multicolumn{4}{|c|}{ Specification } \\
\hline & {$[1]$} & {$[2]$} & {$[3]$} & {$[4]$} \\
\hline Log real house price & $\mathrm{x}$ & $\mathrm{x}$ & $\mathrm{x}$ & $\mathrm{x}$ \\
\hline Log total houshold population & $\mathrm{x}$ & $\mathrm{x}$ & $\mathrm{x}$ & $\mathrm{x}$ \\
\hline Log old age dependency ratio & $\mathrm{x}$ & $\mathrm{x}$ & $\mathrm{x}$ & $\mathrm{x}$ \\
\hline Log income per capita & $\mathrm{x}$ & $\mathrm{x}$ & $\mathrm{x}$ & $\mathrm{x}$ \\
\hline Log human capital ratio & & & $\mathrm{x}$ & $\mathrm{x}$ \\
\hline Log real mortgage interest rate & & $\mathrm{x}$ & & $\mathrm{x}$ \\
\hline \multicolumn{5}{|l|}{ Cointegration tests } \\
\hline Kao ADF-statistic & $-4.9407 * * *$ & $-3.3990 * * *$ & $-3.9364 * * *$ & $-4.2792 * * *$ \\
\hline Pedroni panel v-statistic & $1.7056 * *$ & -1.4512 & 0.9427 & -2.2468 \\
\hline Pedroni panel rho-statistic & 2.4435 & 5.2398 & 5.0082 & 7.3515 \\
\hline Pedroni panel PP-statistic & $-3.6388 * * *$ & $-2.7785 * * *$ & $-2.1498 * *$ & $-3.3356 * * *$ \\
\hline Pedroni panel ADF-statistic & $-4.1325 * * *$ & $-1.8974 * *$ & $-3.2928 * * *$ & $-2.3632 * * *$ \\
\hline Pedroni group rho-statistic & 5.5255 & 8.3486 & 7.8563 & 10.5082 \\
\hline Pedroni group PP-statistic & $-6.8314 * * *$ & $8.8133 * * *$ & $-8.0500 * * *$ & $-15.6458^{* * *}$ \\
\hline Pedroni group ADF-statistic & $-6.4813 * * *$ & $-4.3851 * * *$ & $-5.4702 * * *$ & $-5.4491 * * *$ \\
\hline
\end{tabular}

$(*, * *, * * *$ denote statistical significance at the $10 \%-, 5 \%$ - and $1 \%$-level, respectively)

\subsection{Results of panel error correction models}

Different techniques are available for the estimation of panel error correction models in which the short-run dynamics are heterogeneous across groups. The mean-group (MG) estimator (Pesaran and Smith 1995) averages the coefficients of $N$ single times-series regressions and allows the intercepts, slope coefficients, and error variances to differ across groups. The pooled mean-group (PMG) estimator (Pesaran et al. 1999) relies on a combination of pooling and averaging the coefficients. As the MG estimator, it allows

\footnotetext{
${ }^{10}$ Following Pedroni (1999), the within-dimension statistics (panel) are constructed by summing both the numerator and the denominator terms over the $N$ dimension separately, whereas the betweendimension (group) statistics are constructed by first dividing the numerator and the denominator, prior to summing over the $N$ dimension. Because the between dimension does not presume a common firstorder autoregressive parameter, it allows modelling an additional source of potential heterogeneity across individual cities.
} 
for heterogeneous short-run dynamics but constrains the long-run elasticities to be equal across all groups. Pooling yields efficient and consistent estimates when the restrictions are true. Common dynamic fixed-effects estimation (DFE) captures individual unobserved effects on house prices across cities. Like the PMG estimator, it restricts the coefficients of the cointegrating vector to be homogenous across cities. The speed of adjustment coefficient and the short-run coefficients are also assumed as equal.

Building on the baseline regression model, we define the long-run price function as follows:

$P_{i t}=\beta_{0}+\beta_{1 t} D_{i t}+\beta_{2 t} E_{i t}+\mu_{i}+\varepsilon_{i t}$

where $P_{i t}$ is the log real house price, $D_{i t}$ is the vector of explanatory demographic variables, $E_{i t}$ is the vector of explanatory economic variables, and $\mu_{i}$ is the groupspecific unobserved effect. In line with the previous section, we assume that the variables in levels follow an I(1) process and are cointegrated. The $\operatorname{ARDL}(1,1,1)$ dynamic panel specification of $(3)$ is:

$P_{i t}=\delta_{10 i} D_{i t}+\delta_{11 i} D_{i, t-1}+\delta_{20 i} E_{i t}+\delta_{21 i} E_{i, t-1}+\lambda_{i} P_{i, t-1}+\mu_{i}+\varepsilon_{i t}$

where $\lambda_{i}$ are scalars. The error correction representation of (4) is:

$\Delta P_{i t}=\delta_{11 t} \Delta D_{i t}+\delta_{21 t} \Delta E_{i t}+\phi_{i}\left(P_{i, t-1}-\beta_{0 i}-\beta_{1 i} D_{i t}-\beta_{2 i} E_{i t}\right)+\varepsilon_{i t}$

where $\phi_{i}=-\left(1-\lambda_{i}\right), \beta_{0 i}=\frac{\mu_{i}}{1-\lambda_{i}}, \beta_{1 i}=\frac{\delta_{10 i}+\delta_{11 i}}{1-\lambda_{i}}$, and $\beta_{2 i}=\frac{\delta_{20 i}+\delta_{21 i}}{1-\lambda_{i}}$. The estimated coefficients $\beta_{1 i}$ and $\beta_{2 i}$ capture the long-run real house price effects of local demographic and economic fundamentals and can readily be interpreted as elasticities. If the variables return to long-run equilibrium after a shock, the error-correction adjustment parameter $\phi_{i}$ is expected to have a negative sign.

Our baseline regression model [1] explains the evolution of real urban house prices with the temporal evolutions of the total number of resident households, old age dependency ratios, and the real city income per capita. The additional price determinants are subsequently combined with this baseline specification. From theory, we expect the elasticities of real house prices to be positive with respect to the number of households, real per capita income, and the human capital ratio. Negative long-run elasticities are meanwhile expected with respect to the old age dependency ratio and the national real mortgage interest rate.

The results of estimating each different specification with the MG, PMG and DFE estimators are shown in Table 4. Since the MG and PMG estimators are inconsistent if the true data-generating process includes unobserved city heterogeneity, we employ the common Hausman test to each specification. The Hausman test indicates the presence of unobserved city fixed-effects, such that we focus the discussion of our results on the 
DFE-estimation. As favorite specification, we identify the DFE Specification [2], which includes only significant explanatory variables. ${ }^{11}$

Table 4. Results of different panel error correction model specifications

\begin{tabular}{|c|c|c|c|c|}
\hline \multirow[b]{2}{*}{ Pooled mean-group estimation } & \multicolumn{4}{|c|}{ Specification } \\
\hline & {$[1]$} & {$[2]$} & {$[3]$} & {$[4]$} \\
\hline Log total houshold population & $1.5415 * * *$ & $1.0677 * * *$ & $1.2196 * * *$ & $0.7268 * * *$ \\
\hline Log old age dependency ratio & $-1.1603 * * *$ & $-1.3009 * * *$ & $-1.4495 * * *$ & $-1.2551 * * *$ \\
\hline Log income per capita & $0.1891 * * *$ & $0.3517 * * *$ & $0.1630 * * *$ & $0.3001 * * *$ \\
\hline Log human capital ratio & & & $0.1377 * * *$ & $-0.1455 * * *$ \\
\hline Log real mortgage interest rate & & $-0.0776 * * *$ & & $-0.1379 * * *$ \\
\hline Error correction term & $-0.3029 * * *$ & $-0.2730 * * *$ & $-0.3022 * * *$ & $-0.3072 * * *$ \\
\hline \multicolumn{5}{|l|}{ Mean-group estimation } \\
\hline Log total houshold population & $1.6801 *$ & $2.4003 * *$ & 4.7370 & 1.7768 \\
\hline Log old age dependency ratio & $-1.5237 * * *$ & $-2.2503 * * *$ & $-2.9243 * * *$ & $-1.1854 * *$ \\
\hline Log income per capita & 0.4342 & 0.8999 & -1.8570 & -0.0645 \\
\hline Log human capital ratio & & & 0.2710 & 0.0583 \\
\hline Log real mortgage interest rate & & $-0.0537 *$ & & $-0.1378 * *$ \\
\hline Error correction term & $-0.6227 * * *$ & $-0.6698 * * *$ & $-0.7380 * * *$ & $-0.8450 * * *$ \\
\hline \multicolumn{5}{|l|}{ Dynamic fixed-effects estimation } \\
\hline Log total houshold population & $1.6581 * * *$ & $1.3847 * * *$ & $1.5043 * * *$ & $1.3519 * * *$ \\
\hline Log old age dependency ratio & $-1.2634 * * *$ & $-1.8283 * * *$ & $-1.4991 * * *$ & $-1.8682 * * *$ \\
\hline Log income per capita & $0.3020 * *$ & $0.3589 * *$ & $0.3493 * *$ & $0.3677 * * *$ \\
\hline Log human capital ratio & & & $0.2106 * * *$ & 0.0322 \\
\hline Log real mortgage interest rate & & $-0.2763 * * *$ & & $-0.2698 * * *$ \\
\hline Error correction term & $-0.1635 * * *$ & $|-0.1318 * * *|$ & $|-0.1437 * * *|$ & $-0.1306 * * *$ \\
\hline
\end{tabular}

The estimated signs for the coefficients of the long-run cointegration relationship between real urban house prices and their demographic and economic fundamentals generally conform to the theoretical expectations. The results support our key hypothesis that population aging is associated with decreasing house prices. The coefficient estimated with the old age dependency ratio carries the expected negative sign and is significantly different from zero. An increase in the old age dependency ratio of one per cent implies 1.83 per cent lower real house prices in the long run on average, which is an economically very meaningful effect. Another key demographic driver of real local house prices is total household population: a one per cent increase in the number of resident households is associated with a 1.38 per cent average increase in prices in the long run. Regarding other controlling covariates, an increase in real city income per capita of one per cent is associated with a 0.36 per cent long-run increase in real house prices. The human capital ratio is statistically insignificant in the DFE estimation

${ }^{11}$ The Hausman test favors the DFE model prior to PMG model and lastly, the MG model. 
when national mortgage interest rates are included. Upward shifts in housing financing costs of one per cent at the national level meanwhile shift downward urban home prices by 0.28 per cent on average. This estimate implies that urban house prices in Germany decrease by about 30 per cent on average in the long run if the national mortgage interest rate doubles. ${ }^{12}$ Regarding the error correction behavior of house prices, the coefficient estimated for the speed of adjustment of error correction is negative and significant, which is in line with theoretical expectations that real urban house prices return to their long-run equilibrium values after demographic or economic shocks. Yet, the small size of the adjustment parameter suggests that real prices stay depart from their equilibrium values for prolonged periods of time.

Table 5 contrasts our findings with the results of the two recent relevant studies of Takáts (2012) and Saita et al. (2013). Although such direct comparison is naturally limited by differences in specification and data, it illustrates a striking similarity of the results. ${ }^{13}$ The coefficient we find for the elasticity of real house prices with respect to total population $(+1.38)$ lies slightly below the respective coefficients that Saita et al. measure for regions in Japan $(+2.02)$ and the US $(+1.81)$ in the most comparable specification, whereas it is larger than the respective elasticity that Takáts finds for OECD countries $(+1.05)$. Some of these differences may reflect that our population measure is less noisy, though our results appear to be largely insenstive to the use of households versus individual population. ${ }^{14}$ The real house price elasiticity we find with respect the old age dependency ratio $(-1.83)$ ranges above the respective elasticities that Saita et al. find for US states (-0.54) and Japanase prefectures (-1.73) in absolute terms. It is also more than one percentage point larger than the ratio Takáts finds for OECD countries (-0.68).

The empirial relationship between real house prices and real per capita incomes is quite comparable among the three studies. Importantly, all studies find the respective elasticity to be positive and less than one. Our elasticity measure of +0.36 lies between that which Saita et al. find for Japanese prefectures $(+0.23)$ and for US states $(+0.45)$. In OECD countries, the real income elasticity of house prices appears to be considerably higher (+0.88). Such large elasticity estimates may, however, reflect measurement error due to aggregation problems in national data.

In summary, our econometric results yield new original evidence supporting the theoretical claim that local demography acts as a strong driver of returns to housing capital over the long run. Concerning the effect of aging, there is now robust evidence of an

\footnotetext{
${ }^{12}$ A coefficient of this size suggests that the European Central Bank's low interest rate policy in response to the financial crisis plays an important role in the substantial increase in real housing prices in many German cities since 2009.

${ }^{13}$ Following Takáts, we also estimated a pooled OLS regression, the results of which are provided in the Appendix.

${ }^{14}$ If we use population instead of household figures, we find the following elasticities in our DFE estimation: $\log$ total population: 1.6799, log old age dependency ratio: $-1.1698, \log$ income per capita: 0.3631 . Further results are provided in the Appendix.
} 
economically meaningful negative effect of increases in the old-age dependency ratio on house prices at the local, the regional and the national level.

Table 5. Comparison of estimated elasticities in different studies ${ }^{15}$

\begin{tabular}{|c|c|c|c|c|c|c|}
\hline \multicolumn{2}{|l|}{ Results } & \multicolumn{3}{|c|}{ Saita et al. (2013) } & \multicolumn{2}{|l|}{ Takáts (2012) } \\
\hline Variables & Germany & Variables & Japan & U.S. & Variables & Nation \\
\hline Panel units $(\mathrm{N})$ & 87 cities & Panel units $(\mathrm{N})$ & 47 prefectures & 50 states & Panel units (N) & 22 countries \\
\hline Time periods $(\mathrm{T})$ & 18 years & Time periods $(\mathrm{T})$ & 34 years & 36 years & Time periods $(\mathrm{T})$ & 40 years \\
\hline Log real resale apartment price & & Log real land / housing price & & & Log real house price & \\
\hline Log total houshold population & 1.3847 & Log total population & 2.0220 & 1.8079 & Log total population & 1.0547 \\
\hline Log old age dependency ratio & -1.8283 & Log old age dependency ratio & -1.7280 & -0.5363 & Log old age dependency ratio & -0.6818 \\
\hline Log income per capita & 0.3589 & Log GDP per capita & 0.2302 & 0.4525 & Log GDP per capita & 0.8842 \\
\hline Error correction term & -0.1635 & Error correction term & -0.1056 & -0.1199 & Error correction term & $\mathrm{N} / \mathrm{A}$ \\
\hline
\end{tabular}

\subsection{Probabilistic forecasts of demography-related house price effects}

We use the DFE estimation results of the panel error correction model for a conditional probabilistic forecast of expected demography-related local house price effects until 2020. To this end, we first multiply the annual expected percentage change of total household population and the old age dependency ratio in each city ${ }^{16}$ with their respective real house price elasticities estimated in the favorite DFE specification. We then compute the mean annual expected real house price change, which is conditional in the sense that real incomes and financing costs remain unchanged Based on the standard errors of the two respective elasticity estimates, we also provide a 90 per cent confidence interval for the annual price effect. In Table 6, the 87 cities in the sample are ranked according to the total size of the mean expected annual demography-induced price effect.

In almost the entire sample, local demographic change will most likely lead to lower real house prices until 2020, ceteris paribus. The strongest negative demographyinduced price effects must be expected for cities in eastern Germany. Many of these cities have experienced severe price declines in the past. The expected annual demography-induced price change is positive only for one city (Dusseldorf). In order to interpret these projections appropriately, it is important to remember that they assume that all other relevant price-explaining factors remain constant. In each city, negative demography-induced price effects may in fact be (over-)compensated by gains to productivity, lower real housing financing costs, or unobserved city-level effects. Of course, since the exact size of the regression coefficients is sensitive to the specification (Table 4) and local demographic forecasts by themselves probabilistic, the exact quantitative values must not be overstated relative to their qualitative implications.

\footnotetext{
15 The results of Saita et al. (2013) refer to their baseline specification of a panel error correction model including regional fixed effects. The results of Tákats refer to a pooled OLS model in first differences including time fixed effects.

${ }^{16}$ Data on household and population age structure projections is provided by the German Federal Institute for Research on Building, Urban Affairs and Spatial Development (BBSR 2009).
} 
In Figure 5, we graphically split the combined impact of demography into the specific contributions of household population growth and aging for a deeper understanding of expected demography-related house price effects. The graph illustrates that the major part of the expected adverse demography-induced house price effects in German cities until 2020 is a consequence of expected gradual increases in the old age dependency ratio. Growing housing services demand due to increasing household numbers will by itself attenuate annual average house price decline in many cities. In some cities, the positive partial price impact of household growth is likely to compensate for the negative partial price impact of aging to a significant extent. 
Table 6. Demography-induced annual change to urban house prices in per cent, 2020

\begin{tabular}{|c|c|c|c|c|c|c|c|c|c|}
\hline \multirow[t]{2}{*}{ Rank } & \multirow[t]{2}{*}{ City } & \multicolumn{3}{|c|}{$90 \%$ confidence interval } & \multirow[t]{2}{*}{ Rank } & \multirow[t]{2}{*}{ City } & \multicolumn{3}{|c|}{$90 \%$ confidence interval } \\
\hline & & minimum & mean & maximum & & & minimum & mean & maximum \\
\hline 1 & Dusseldorf & -0.17 & 0.20 & 0.58 & 45 & Frankfurt (Main) & -2.78 & -2.15 & -1.52 \\
\hline 2 & Bamberg & -0.40 & -0.07 & 0.25 & 46 & Offenbach (Main) & -2.79 & -2.18 & -1.57 \\
\hline 3 & Bielefeld & -0.34 & -0.12 & 0.11 & 47 & Kempten (Allgau) & -2.69 & -2.20 & -1.70 \\
\hline 4 & Hamburg & -0.49 & -0.16 & 0.16 & 48 & Wuppertal & -2.44 & -2.23 & -2.01 \\
\hline 5 & Regensburg & -0.77 & -0.31 & 0.15 & 49 & Potsdam & -3.17 & -2.28 & -1.39 \\
\hline 6 & Rosenheim & -0.85 & -0.34 & 0.17 & 50 & Freiburg (Breisgau) & -3.26 & -2.39 & -1.51 \\
\hline 7 & Leverkusen & -0.57 & -0.39 & -0.21 & 51 & Kaiserslautern & -2.88 & -2.40 & -1.91 \\
\hline 8 & Cologne & -0.85 & -0.40 & 0.04 & 52 & Heidelberg & -3.10 & -2.41 & -1.72 \\
\hline 9 & Ludwigshafen & -1.17 & -0.74 & -0.30 & 53 & Dresden & -3.02 & -2.45 & -1.87 \\
\hline 10 & Stuttgart & -1.32 & -0.82 & -0.33 & 54 & Hagen & -2.48 & -2.46 & -2.43 \\
\hline 11 & Heilbronn & -1.36 & -0.86 & -0.36 & 55 & Bochum & -2.77 & -2.48 & -2.18 \\
\hline 12 & Augsburg & -1.37 & -0.90 & -0.43 & 56 & Coburg & -2.77 & -2.51 & -2.25 \\
\hline 13 & Munich & -1.53 & -0.92 & -0.30 & 57 & Furth & -3.23 & -2.54 & -1.86 \\
\hline 14 & Erlangen & -1.35 & -0.93 & -0.50 & 58 & Neumunster & -2.93 & -2.58 & -2.23 \\
\hline 15 & Brunswick & -1.30 & -1.01 & -0.71 & 59 & Bayreuth & -3.08 & -2.75 & -2.42 \\
\hline 16 & Landshut & -1.78 & -1.03 & -0.29 & 60 & Hamm & -3.26 & -2.78 & -2.30 \\
\hline 17 & Mainz & -1.68 & -1.06 & -0.45 & 61 & Wilhelmshaven & -3.07 & -2.81 & -2.55 \\
\hline 18 & Osnabruck & -1.44 & -1.07 & -0.70 & 62 & Remscheid & -2.90 & -2.82 & -2.74 \\
\hline 19 & Nuremberg & -1.62 & -1.12 & -0.63 & 63 & Bremerhaven & -3.13 & -2.85 & -2.57 \\
\hline 20 & Wiesbaden & -1.76 & -1.23 & -0.70 & 64 & Kassel & -3.22 & -2.87 & -2.53 \\
\hline 21 & Flensburg & -1.63 & -1.25 & -0.86 & 65 & Leipzig & -3.46 & -2.93 & -2.41 \\
\hline 22 & Wurzburg & -1.70 & -1.28 & -0.86 & 66 & Herne & -3.22 & -2.99 & -2.75 \\
\hline 23 & Trier & -1.93 & -1.42 & -0.92 & 67 & Gelsenkirchen & -3.27 & -3.06 & -2.84 \\
\hline 24 & Bremen & -1.76 & -1.44 & -1.12 & 68 & Aschaffenburg & -3.81 & -3.08 & -2.35 \\
\hline 25 & Lubeck & -1.71 & -1.45 & -1.20 & 69 & Berlin & -3.86 & -3.27 & -2.67 \\
\hline 26 & Bonn & -2.08 & -1.48 & -0.87 & 70 & Darmstadt & -4.04 & -3.29 & -2.54 \\
\hline 27 & Ingolstadt & -2.28 & -1.59 & -0.90 & 71 & Oberhausen & -3.80 & -3.31 & -2.82 \\
\hline 28 & Oldenburg & -2.32 & -1.62 & -0.92 & 72 & Monchengladbach & -3.82 & -3.34 & -2.87 \\
\hline 29 & Wolfsburg & -1.86 & -1.64 & -1.41 & 73 & Weimar & -4.03 & -3.44 & -2.84 \\
\hline 30 & Mulheim (Ruhr) & -1.83 & -1.64 & -1.44 & 74 & Bottrop & -4.22 & -3.78 & -3.34 \\
\hline 31 & Solingen & -1.85 & -1.67 & -1.48 & 75 & Salzgitter & -4.13 & -3.97 & -3.80 \\
\hline 32 & Ulm & -2.32 & -1.69 & -1.07 & 76 & Jena & -5.01 & -4.38 & -3.76 \\
\hline 33 & Mannheim & -2.32 & -1.79 & -1.25 & 77 & Magdeburg & -5.56 & -5.15 & -4.75 \\
\hline 34 & Koblenz & -2.22 & -1.79 & -1.37 & 78 & Brandenburg (Havel) & -5.83 & -5.52 & -5.21 \\
\hline 35 & Duisburg & -1.97 & -1.80 & -1.63 & 79 & Erfurt & -6.53 & -5.83 & -5.13 \\
\hline 36 & Karlsruhe & -2.46 & -1.86 & -1.25 & 80 & Rostock & -6.90 & -6.32 & -5.74 \\
\hline 37 & Essen & -2.16 & -1.88 & -1.60 & 81 & Halle (Saale) & -7.47 & -7.02 & -6.58 \\
\hline 38 & Passau & -2.44 & -1.90 & -1.36 & 82 & Chemnitz & -7.56 & -7.14 & -6.71 \\
\hline 39 & Kiel & -2.32 & -1.90 & -1.48 & 83 & Schwerin & -8.62 & -7.96 & -7.31 \\
\hline 40 & Dortmund & -2.28 & -1.91 & -1.54 & 84 & Gera & -9.89 & -9.40 & -8.91 \\
\hline 41 & Munster & -2.72 & -2.00 & -1.29 & 85 & Cottbus & -10.22 & -9.54 & -8.87 \\
\hline 42 & Krefeld & -2.29 & -2.02 & -1.75 & 86 & Frankfurt (Oder) & -11.15 & -10.43 & -9.72 \\
\hline 43 & Schweinfurt & -2.42 & -2.13 & -1.84 & 87 & Suhl & -11.96 & -11.36 & -10.76 \\
\hline 44 & Pforzheim & -2.71 & -2.14 & -1.57 & & & & & \\
\hline
\end{tabular}

Source: Authors' own calculations. 
Figure 5. Partial impacts of age structure and household numbers on urban house prices in per cent, 2020

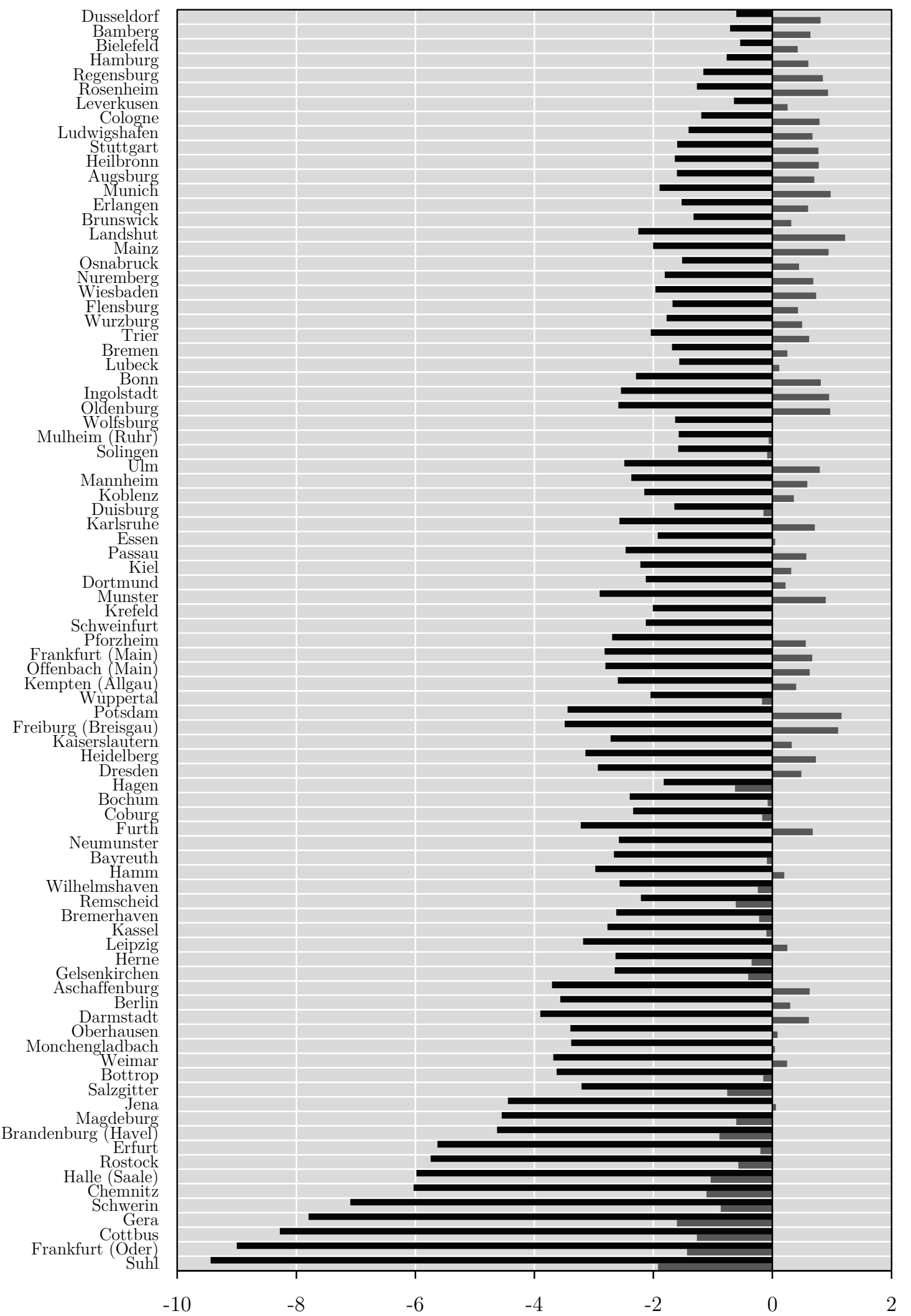

- Impact of old age dependency ratio

- Impact of total household population

Source: Authors' own calculations. 


\section{Conclusions}

How urban house prices are affected by demographic change in industrialized countries in the long run is of critical relevance for home owners, investors, and policy makers alike. The results of this paper provide original empirical evidence that the effects of local aging and population shrinkage on city-level house prices are negative and economically meaningful. This evidence adds to recent related findings by other researchers using national and regional level housing market data. Extrapolating historical empirical relationships to the future of urban house prices, demographic change is most likely to contribute to lower real home price growth in almost any German urban area until 2020. This represents an amplification of the already existing headwind effects that demographic development have imposed on German home prices over recent years.

As with any projections, the results of our probabilistic forecast of city-level demography-induced house prices have to be treated with the appropriate care. The causal mechanisms underlying the empirical links between house prices and demography can and do change with changes in household preferences, housing finance institutions and the design of pension systems. Urban demographic developments may also not be fully exogenous to urban house prices, given that rational households chose locations based inter alia on intercity house price differences. Another factor that influences the price effect of demographic shifts at the urban level is housing supply. Our results indicate that housing supply has been finitely elastic over the sample period of 1995-2012, because it is not possible to find such large price effects otherwise. ${ }^{17}$ Future increases in the elasticity of housing supply can theoretically reduce the real price effects of forthcoming shifts to urban housing demand. However, given the durability-related downward stickiness of housing supply, we see strong signs that aging and shrinking cities in Germany and elsewhere will encounter considerable difficulty in combating future demography-induced negative gains to housing capital within the relevant time horizons.

Future research could use our findings as a starting point for further work on the potential endogeneity between aging and house prices. Do price declines due to an aging society provoke young people to move in or move out of a city? As adverse price effects of aging make urban owner-occupied housing more affordable, this might encourage young households to invest in an aging city. As Hiller and Lerbs (2015) show, it may be necessary to account for the evolution of urban amenities to disentangle these dynamic second-round effects.

\footnotetext{
${ }^{17}$ Lerbs (2014) provides econometric evidence at the German district level that housing supply in Germany is indeed inelastic, finding a long-run elasticity estimate of 0.33 for single-family homes.
} 


\section{References}

N. Apergis, O.C. Dincer, and J.E. Payne. The relationship between corruption and income ine quality in US states: evidence from a panel cointegration and error correction model. Public Choice, 145(1-2): 125-135, 2010.

A. Banerjee. Panel data unit roots and cointegration: an overview. Oxford Bulletin of Economics and Statistics, 61(S1): 607-629, 1999.

M. Beenstock, D. Felsenstein. Spatial error correction and cointegration in nonstationary panel data: regional house prices in Israel. Journal of Geographic Systems, 12(2): 189-206, 2010.

M. Bernt. Partnerships for Demolition: The Governance of Urban Renewal in East Germany's Shrinking Cities. International Journal of Urban and Regional Research, 33(3): 754-769, 2009.

R.R. Brady. Measuring the diffusion of housing prices across space and over time. Journal of Applied Econometrics, 26(2): 213-231, 2011.

BBSR. Raumordnungsprognose 2030. German Federal Institute for Research on Building, Urban Affairs and Spatial Development, http://www.bbsr.bund.de/BBSR/DE/Raumbeobachtung/UeberRaumbeobachtung/Kompon e-ten/Raumordnungsprognose/Downloads/DL_uebersicht.html;jsessionid=B1988D65EFA16 FA81A0E61D4494D0A93.live1043?nn=443714, 2009.

D.R. Capozza, P.H. Hendershott, C. Mack, C.J. Mayer. Determinants of real house price dynamics. NBER Working Paper No. 9262, 2002.

G.A. Carlino, R.H. DeFina. Macroeconomic analysis using regional data: An application to monetary policy. In: R. J. Arnott and D. P. McMillen (Eds.) A Companion to Urban Economics, 440-459, Blackwell Publishing Ltd, Oxford, UK, 2008.

I. Choi. Unit root tests for panel data. Journal of International Money and Finance, 20(2): 249-272, 2001.

Destatis. Germany's population by 2060 - Results of the $12^{\text {th }}$ coordinated population projection. German Federal Statistical Office, Wiesbaden, https://www.destatis.de/EN/Publications/Specialized/Population/GermanyPopulation2060. pdf?__blob=publicationFile, 2009.

D. DiPasquale, W.C. Wheaton. Housing Market Dynamics and the Future of Housing Prices. Journal of Urban Economics, 35(1): 1-27, 1994.

M. Eberhardt, E. Teal. Econometrics for Grumblers: A New Look at the Literature on CrossCountry Growth Empirics. Journal of Economic Surveys, 25(1): 109-155, 2011. 
P. Eichholtz, T. Lindenthal. Demographics, human capital, and the demand for housing. Journal of Housing Economics, 26(1): 19-32, 2014.

R.F. Engle, C.W.J. Granger. Cointegration and error correction: Representation, estimtation and testing. Econometrica, 55(2): 251-276, 1987

J. Ermisch. The demand for housing in Britain and population ageing: Microeconometric evidence. Economica, 63(251): 383-404, 1996.

M. Flavin, T. Yamashita. Owner-Occupied Housing and the Composition of the Household Portfolio. American Economic Review, 92(1): 345-362, 2002.

J. Gallin. The long-run relationship between house prices and rents. Real Estate Economics, 36(4): 635-658, 2008.

A.C. Goodman, T.G. Thibodeau. Where are the speculative bubbles in US housing markets? Journal of Housing Economics, 17(2): 117-137, 2008.

E.L. Glaeser, J. Gyourko, A. Saiz. Housing supply and housing bubbles. Journal of Urban Economics, 64(2): 198-217, 2008

R. Green, P.H. Hendershott. Age, housing demand, and real house prices. Regional Science and Urban Economics, 26(5): 465-480, 1996.

J.D. Hamilton. Time Series Analysis. Princeton University Press, 1994.

R.D.F. Harris, E. Tzavalis. Inference for unit roots in dynamic panels where the time dimension is fixed. Journal of Econometrics, 91(2): 201-226, 1999.

J.V. Henderson, Y.M. Ioannides. A Model of Housing Tenure Choice. American Economic Review, 73(1): 98-113, 1983.

N. Hiller, O. Lerbs. The capitalization of non-market attributes into regional housing rents and wages: evidence on German functional labor market areas. Review of Regional Research, 35(1): 49-72, 2015.

C. Himmelberg, C. Mayer, T. Sinai. Assessing high house prices: Bubbles, fundamentals and misperceptions. The Journal of Economic Perspectives, 19(4): 67-92, 2005.

S. Holly, M.H. Pesaran, and T. Yamagata. A spatio-temporal model of house prices in the USA. Journal of Econometrics, 158(1): 160-173, 2010.

K.S. Im, M.H. Pesaran, Y. Shin. Testing for unit roots in heterogeneous panels. Journal of Econometrics, 115(1): 53-74, 2003. 
F. Kajuth, T.A. Knetsch, N. Pinkwart. Assessing house prices in Germany: evidence from an estimated stock-flow model using regional data. Deutsche Bundesbank Discussion Paper No. 46, 2013.

C. Kao. Spurious regression and residual-based tests for cointegration in panel data. Journal of Economcetrics, 90(1): 1-44, 1999.

H. Kraft, C. Munk. Optimal Housing, Consumption, and Investment Decisions over the Life Cycle. Management Science, 57(6): 1025-1041, 2011.

T.H. Kuethe, V.O. Pede. Regional Housing Price Cycles: A Spatio-temporal Analysis Using US State-level Data. Regional Studies, 45(5): 563-574, 2011.

C.C. Lee, M.S. Chien. Empirical modelling of regional house prices and the ripple effect. Urban Studies, 48(10): 2029-2047, 2011.

O. Lerbs. House prices, housing development costs, and the supply of new single-family housing in German counties and cities. Journal of Property Research, 31(3): 183-210, 2014.

A. Levin, C.F. Lin, C.S.J. Chu. Unit root tests in panel data: asymptotic and finite-sample properties. Journal of Econometrics, 108(1): 1-24, 2002.

N.G. Mankiw and D.N. Weil. The baby boom, the baby bust, and the housing market. Regional Science and Urban Economics, 19(2): 235-258, 1989.

W. Maennig, L. Dust. Shrinking and growing metropolitan areas asymmetric real estate price reactions? The case of German single-family houses. Regional Science and Urban Economics, 38(1): 63-69, 2008.

G. Meen. Regional house prices and the ripple effect: a new interpretation. Housing Studies, 14(6): 733-753, 1999.

A.R. Mian, A. Sufi. House prices, home equity-based borrowing, and the US household leverage crisis. NBER Working Paper No. 15283, 2009.

N. Miller and L. Peng. Exploring Metropolitan Housing Price Volatility. Journal of Real Estate Finance and Economics, 33: 5-18, 2006.

P. Pedroni. Critical Values for Cointegration Tests in Heterogeneous Panels with Multiple Regressors. Oxford Bulletin of Economics and Statistics, 61(S1): 653-670, 1999.

P. Pedroni. Panel Cointegration: Asymptotic and Finite Sample Properties of Pooled Time Series Tests with an Application to the PPP Hypothesis. Econometric Theory, 20(3): 597625,2004 . 
M.H. Pesaran and R.P. Smith. Estimating long-run relationships from dynamic heterogeneous panels. Journal of Econometrics, 68(1): 79-113, 1995.

M.H. Pesaran, Y. Shin, and R.P. Smith. Pooled mean group estimation of dynamic heterogeneous panels. Journal of the American Statistical Association, 94(446): 621-634, 1999.

P.C.B. Phillips and H.R. Moon. Nonstationary panel data analysis: an overview of some recent developments. Econometric Reviews, 19(3): 263-286, 2000.

J.R. Pitkin, D. Myers. The Specification of Demographic Effects on Housing Demand: Avoiding the Age-Cohort Fallacy. Journal of Housing Economics, 3(3): 240-250, 1994.

S.S. Rosenthal, W.C. Strange. Evidence on the nature and sources of agglomeration economies. In: J.V. Henderson, J.-F. Thisse (Eds.) Handbook of Regional and Urban Economics, Vol. 4, 2119-2171, Elsevier, Amsterdam, 2004.

Y. Saita, C. Shimizu, T. Watanabe. Aging and Real Estate Prices: Evidence from Japanese and US Regional Data, Working Paper Series 028, 2013.

E. Takáts. Aging and house prices. Journal of Housing Economics, 21(2): 131-141, 2012.

B. Zhu, R. Füss, N. Rottke (2013). Spatial Linkages in Returns and Volatilities among U.S. Regional Housing Markets. Real Estate Economics, 41(1): 29-64, 2013 


\section{Appendix}

Table A1. Summary statistics (mean, std. dev. in parentheses), 1995-2012

\begin{tabular}{|c|c|c|c|c|c|c|}
\hline No. & City & $\begin{array}{c}\text { Real house } \\
\text { price (EUR) }\end{array}$ & $\begin{array}{c}\text { Total houshold } \\
\text { population }\end{array}$ & $\begin{array}{c}\text { Old age } \\
\text { dependency ratio }\end{array}$ & $\begin{array}{c}\text { Income per capita } \\
\text { (EUR) }\end{array}$ & $\begin{array}{c}\text { Human capital } \\
\text { ratio }\end{array}$ \\
\hline 1 & Flensburg & $1160(192)$ & $45033(2014)$ & $0.3(0.01)$ & 71386 (5311) & $0.4(0.12)$ \\
\hline 2 & Kiel & $1541(276)$ & $132783(1987)$ & $0.26(0.02)$ & $72652(2074)$ & $0.78(0.16)$ \\
\hline 3 & Lubeck & $1515(210)$ & $119650(1518)$ & $0.35(0.03)$ & 64019 (1912) & $0.48(0.11)$ \\
\hline 4 & Neumunster & $1361(256)$ & $38683(285)$ & $0.33(0.04)$ & $64862(1747)$ & $0.35(0.07)$ \\
\hline 5 & Hamburg & $2272(204)$ & $949633(35913)$ & $0.28(0.02)$ & $100218(3005)$ & $0.92(0.24)$ \\
\hline 6 & Brunswick & $1335(245)$ & $135472(3196)$ & $0.32(0.02)$ & 71605 (1251) & $0.84(0.24)$ \\
\hline 7 & Salzgitter & $1203(210)$ & 55661 (1208) & $0.35(0.05)$ & 75299 (7313) & $0.38(0.12)$ \\
\hline 8 & Wolfsburg & $1294(229)$ & $61961(1044)$ & $0.35(0.05)$ & $170174(28571)$ & $0.87(0.62)$ \\
\hline 9 & Oldenburg & $1362(239)$ & $83522(3562)$ & $0.27(0.02)$ & $70793(1812)$ & $0.67(0.21)$ \\
\hline 10 & Osnabruck & $1469(217)$ & 85389 (1526) & $0.29(0.02)$ & 80770 (2349) & $0.53(0.13)$ \\
\hline 11 & Wilhelmshaven & $1003(244)$ & $43550(825)$ & $0.36(0.05)$ & 74714 (5288) & $0.43(0.09)$ \\
\hline 12 & Bremen & $1438(181)$ & $292789(8812)$ & $0.31(0.03)$ & $85741(3230)$ & $0.82(0.19)$ \\
\hline 13 & Bremerhaven & $1005(192)$ & $63667(1582)$ & $0.34(0.03)$ & $65378(3780)$ & $0.38(0.12)$ \\
\hline 14 & Dusseldorf & $2254(250)$ & $303200(7250)$ & $0.29(0.02)$ & $136138(3480)$ & $1(0.28)$ \\
\hline 15 & Duisburg & $1466(230)$ & $247511(3309)$ & $0.33(0.03)$ & $65360(3703)$ & $0.43(0.11)$ \\
\hline 16 & Essen & 1699 (331) & $295250(2028)$ & $0.34(0.03)$ & 79446 (3986) & $0.81(0.19)$ \\
\hline 17 & Krefeld & $1464(221)$ & $118517(1542)$ & $0.31(0.04)$ & 70439 (3434) & $0.5(0.11)$ \\
\hline 18 & Monchengladbach & $1427(258)$ & $130117(799)$ & $0.3(0.03)$ & $55727(1777)$ & $0.36(0.11)$ \\
\hline 19 & Mulheim (Ruhr) & $1835(181)$ & $84317(502)$ & $0.37(0.04)$ & 76761 (4399) & $0.51(0.13)$ \\
\hline 20 & Oberhausen & $1396(153)$ & $104628(780)$ & $0.32(0.03)$ & $50224(1561)$ & $0.45(0.08)$ \\
\hline 21 & Remscheid & $1479(181)$ & $56700(1491)$ & $0.33(0.04)$ & $67650(2711)$ & $0.33(0.06)$ \\
\hline 22 & Solingen & $1540(224)$ & $80356(426)$ & $0.33(0.04)$ & $51789(1911)$ & $0.22(0.07)$ \\
\hline 23 & Wuppertal & $1393(225)$ & $181672(3796)$ & $0.32(0.03)$ & $61988(1670)$ & $0.43(0.09)$ \\
\hline 24 & Bonn & $1813(105)$ & $160389(5796)$ & $0.28(0.01)$ & $114905(5732)$ & $1.16(0.3)$ \\
\hline 25 & Cologne & 2024 (159) & $520811(14559)$ & $0.26(0.02)$ & $94952(4405)$ & $0.85(0.2)$ \\
\hline 26 & Leverkusen & $1784(270)$ & $79300(1002)$ & $0.33(0.05)$ & $92572(8437)$ & $0.75(0.23)$ \\
\hline 27 & Bottrop & $1479(181)$ & $57239(618)$ & $0.32(0.03)$ & $41547(2465)$ & $0.25(0.05)$ \\
\hline 28 & Gelsenkirchen & $1260(275)$ & $134928(4599)$ & $0.34(0.02)$ & $59025(2957)$ & $0.43(0.14)$ \\
\hline 29 & Munster & $2117(210)$ & $139594(5541)$ & $0.25(0.02)$ & $99945(3771)$ & $0.9(0.15)$ \\
\hline 30 & Bielefeld & $1464(204)$ & $166311(2037)$ & $0.32(0.02)$ & $64844(1372)$ & $0.52(0.12)$ \\
\hline 31 & Bochum & $1568(217)$ & $198422(865)$ & $0.32(0.02)$ & $55816(2814)$ & $0.55(0.11)$ \\
\hline 32 & Dortmund & $1502(225)$ & $289133(3130)$ & $0.32(0.03)$ & $63441(2041)$ & $0.71(0.15)$ \\
\hline 33 & Hagen & $1469(184)$ & $98783(2255)$ & $0.35(0.04)$ & $65778(2278)$ & $0.35(0.09)$ \\
\hline 34 & Hamm & $1271(198)$ & 85078 (1537) & $0.3(0.03)$ & $50986(2513)$ & $0.33(0.08)$ \\
\hline 35 & Herne & $1395(273)$ & $86783(1102)$ & $0.33(0.02)$ & 40390 (1996) & $0.39(0.09)$ \\
\hline 36 & Darmstadt & 2067 (198) & $74672(1922)$ & $0.28(0.01)$ & $106630(4469)$ & $1.26(0.22)$ \\
\hline 37 & Frankfurt (Main) & $2675(90)$ & 355583 (9948) & $0.25(0.01)$ & $154661(5726)$ & $1.2(0.23)$ \\
\hline 38 & Offenbach (Main) & $1761(172)$ & $60839(1125)$ & $0.26(0.02)$ & $69673(5026)$ & $0.78(0.21)$ \\
\hline 39 & Wiesbaden & $2320(330)$ & $141972(3640)$ & $0.29(0.02)$ & $103827(3586)$ & $0.89(0.24)$ \\
\hline 40 & Kassel & $1217(285)$ & $101694(900)$ & $0.31(0.01)$ & $89178(2163)$ & $0.74(0.15)$ \\
\hline 41 & Koblenz & $1543(194)$ & $56161(588)$ & $0.34(0.03)$ & $116652(3076)$ & $0.47(0.1)$ \\
\hline 42 & Trier & $1616(203)$ & $56244(2582)$ & $0.29(0.01)$ & 76775 (4489) & $0.58(0.12)$ \\
\hline 43 & Kaiserslautern & $1286(211)$ & $52378(645)$ & $0.3(0.02)$ & $73635(3346)$ & $0.46(0.11)$ \\
\hline 44 & Ludwigshafen (Rhein) & $1553(247)$ & $81744(959)$ & $0.3(0.03)$ & $130199(5828)$ & $0.62(0.14)$ \\
\hline 45 & Mainz & $1702(162)$ & $100072(4669)$ & $0.25(0.02)$ & $92748(6677)$ & $0.99(0.17)$ \\
\hline
\end{tabular}


Table A1. (Continued)

\begin{tabular}{|c|c|c|c|c|c|c|}
\hline No. & City & $\begin{array}{c}\text { Real house } \\
\text { price (EUR) }\end{array}$ & $\begin{array}{c}\text { Total houshold } \\
\text { population }\end{array}$ & $\begin{array}{c}\text { Old age } \\
\text { dependency ratio }\end{array}$ & $\begin{array}{c}\text { Income per capita } \\
(\mathrm{EUR})\end{array}$ & $\begin{array}{c}\text { Human capital } \\
\text { ratio }\end{array}$ \\
\hline 46 & Stuttgart & $2190(137)$ & $307156(8540)$ & $0.27(0.02)$ & $118480(5842)$ & $1.18(0.28)$ \\
\hline 47 & Heilbronn & $1791(199)$ & $57906(1665)$ & $0.3(0.03)$ & $89443(8596)$ & $0.37(0.06)$ \\
\hline 48 & Karlsruhe & $1832(178)$ & $153872(4044)$ & $0.29(0.01)$ & $97370(3363)$ & $0.76(0.18)$ \\
\hline 49 & Heidelberg & $2463(193)$ & $79428(2261)$ & $0.23(0.01)$ & 88009 (4317) & $1.12(0.23)$ \\
\hline 50 & Mannheim & $1811(302)$ & 160139 (2931) & $0.28(0.02)$ & $99744(4866)$ & $0.69(0.17)$ \\
\hline 51 & Pforzheim & $1709(156)$ & $60028(2071)$ & $0.32(0.03)$ & 69865 (2102) & $0.35(0.09)$ \\
\hline 52 & Freiburg (Breisgau) & $2225(214)$ & $114456(5879)$ & $0.23(0.01)$ & 72404 (3118) & $0.85(0.19)$ \\
\hline 53 & Ulm & $1819(184)$ & $59211(2707)$ & $0.27(0.02)$ & $107404(2758)$ & $0.73(0.17)$ \\
\hline 54 & Ingolstadt & $1856(179)$ & $55950(3887)$ & $0.28(0.02)$ & $130488(23233)$ & $0.61(0.27)$ \\
\hline 55 & Munich & $2923(206)$ & $707367(37403)$ & $0.25(0.02)$ & $108409(4169)$ & $1.28(0.3)$ \\
\hline 56 & Rosenheim & $2165(250)$ & 28433 (1379) & $0.29(0.03)$ & $75575(3612)$ & $0.44(0.11)$ \\
\hline 57 & Landshut & $1747(291)$ & 28717 (1748) & $0.34(0.02)$ & $86823(4555)$ & $0.35(0.07)$ \\
\hline 58 & Passau & $1450(160)$ & $26006(481)$ & $0.32(0.02)$ & $93914(8839)$ & $0.45(0.13)$ \\
\hline 59 & Regensburg & $2105(211)$ & $74233(5268)$ & $0.28(0.01)$ & $122807(7327)$ & $0.78(0.23)$ \\
\hline 60 & Bamberg & $1701(206)$ & $36150(1045)$ & $0.34(0.01)$ & $98090(2418)$ & $0.45(0.11)$ \\
\hline 61 & Bayreuth & $1332(188)$ & $37944(553)$ & $0.3(0.02)$ & 87989 (3174) & $0.47(0.11)$ \\
\hline 62 & Coburg & $1446(231)$ & $20450(263)$ & $0.37(0.02)$ & $102684(16515)$ & $0.54(0.14)$ \\
\hline 63 & Erlangen & $2025(195)$ & $54383(1662)$ & $0.28(0.02)$ & 112169 (9893) & $1.48(0.21)$ \\
\hline 64 & Furth & $1531(146)$ & $57428(1795)$ & $0.28(0.02)$ & $62095(3527)$ & $0.46(0.11)$ \\
\hline 65 & Nuremberg & $1723(239)$ & $258833(6768)$ & $0.31(0.02)$ & $82661(1760)$ & $0.6(0.15)$ \\
\hline 66 & Aschaffenburg & $1709(210)$ & 30961 (1274) & $0.31(0.02)$ & $105174(9469)$ & $0.33(0.06)$ \\
\hline 67 & Schweinfurt & $1159(67)$ & $25250(599)$ & $0.39(0.02)$ & 147194 (14123) & $0.42(0.09)$ \\
\hline 68 & Wurzburg & $1868(163)$ & 73467 (3935) & $0.28(0.01)$ & $85976(5246)$ & $0.64(0.14)$ \\
\hline 69 & Augsburg & $1571(181)$ & $135033(4721)$ & $0.32(0.01)$ & $83724(2521)$ & $0.55(0.14)$ \\
\hline 70 & Kempten (Allgau) & $1589(190)$ & 31933 (1747) & $0.35(0.03)$ & 83667 (4976) & $0.39(0.08)$ \\
\hline 71 & Berlin & $2065(297)$ & $1904589(70324)$ & $0.25(0.03)$ & $52946(1697)$ & $1.03(0.24)$ \\
\hline 72 & Brandenburg (Havel) & $1134(247)$ & $36356(668)$ & $0.34(0.08)$ & $42518(4080)$ & $0.98(0.07)$ \\
\hline 73 & Cottbus & $1293(159)$ & $57611(1594)$ & $0.28(0.06)$ & 49587 (3239) & $1.44(0.23)$ \\
\hline 74 & Frankfurt (Oder) & $1313(277)$ & $31261(1480)$ & $0.27(0.07)$ & $52875(5240)$ & $1.06(0.29)$ \\
\hline 75 & Potsdam & $1985(158)$ & $74272(6758)$ & $0.26(0.04)$ & $59446(2466)$ & $1.64(0.38)$ \\
\hline 76 & Rostock & $1459(241)$ & $108411(4718)$ & $0.29(0.07)$ & $50919(3322)$ & $1.39(0.25)$ \\
\hline 77 & Schwerin & $1442(255)$ & $51000(763)$ & $0.3(0.07)$ & $54460(2818)$ & $1.05(0.2)$ \\
\hline 78 & Chemnitz & $1174(449)$ & $133206(1973)$ & $0.37(0.07)$ & $53137(3639)$ & $1.78(0.16)$ \\
\hline 79 & Dresden & $1847(230)$ & $265872(22771)$ & $0.31(0.04)$ & $55514(4355)$ & $2.03(0.34)$ \\
\hline 80 & Leipzig & $1610(431)$ & $274144(20262)$ & $0.31(0.04)$ & 48844 (2037) & $1.7(0.26)$ \\
\hline 81 & Halle (Saale) & $1317(338)$ & 127439 (2031) & $0.31(0.06)$ & $48192(2396)$ & $1.26(0.17)$ \\
\hline 82 & Magdeburg & $1198(389)$ & $121644(3211)$ & $0.32(0.05)$ & $52788(2667)$ & $1.19(0.16)$ \\
\hline 83 & Erfurt & $1654(402)$ & $105128(5604)$ & $0.28(0.04)$ & 55097 (1001) & $1.49(0.15)$ \\
\hline 84 & Gera & $1182(415)$ & $55094(1075)$ & $0.34(0.07)$ & $40445(2417)$ & $1.12(0.18)$ \\
\hline 85 & Jena & $1713(268)$ & $52811(3829)$ & $0.26(0.04)$ & $51300(6458)$ & $2.65(0.53)$ \\
\hline 86 & Suhl & $1319(332)$ & 20894 (1148) & $0.31(0.09)$ & $42601(3863)$ & $1.52(0.11)$ \\
\hline 87 & Weimar & $1422(270)$ & $31806(2476)$ & $0.29(0.03)$ & 41556 (1809) & $2.04(0.33)$ \\
\hline
\end{tabular}


Table A2. Panel unit root tests (with total population) ${ }^{18}$

\begin{tabular}{|c|c|c|c|c|c|c|}
\hline Variables & \multicolumn{2}{|c|}{ Levin-Lin-Chu } & \multicolumn{2}{|c|}{ Im-Pesaran-Shin } & \multicolumn{2}{|c|}{ Harris-Tzavalis } \\
\hline & $\begin{array}{r}\mathrm{H}_{0}: e_{i}= \\
\mathrm{H}_{\mathrm{a}}: \\
\mathrm{T} \rightarrow \infty\end{array}$ & $\begin{array}{l}\text { for all i } \\
<1 \\
N \rightarrow \infty\end{array}$ & $\begin{array}{r}\mathrm{H}_{0}: e_{i}= \\
\mathrm{H}_{\mathrm{a}}: \\
\mathrm{T} \text { is fixed }\end{array}$ & $\begin{array}{l}1 \text { for all } \mathrm{i} \\
{ }_{i}<1 \\
\mathrm{~N} \text { is fixed }\end{array}$ & $\begin{array}{r}\mathrm{H}_{0}: \\
\mathrm{H}_{\mathrm{a}} \text { : } \\
\mathrm{T} \text { is fixec }\end{array}$ & $\begin{array}{l}=1 \\
<1 \\
N \rightarrow \infty\end{array}$ \\
\hline & $\begin{array}{c}\text { No trend } \\
\text { Test statistic }\end{array}$ & $\begin{array}{c}\text { Trend } \\
\text { Test statistic }\end{array}$ & $\begin{array}{c}\text { No trend } \\
\text { Test statistic }\end{array}$ & $\begin{array}{c}\text { Trend } \\
\text { Test statistic }\end{array}$ & $\begin{array}{c}\text { No trend } \\
\text { Test statistic }\end{array}$ & $\begin{array}{c}\text { Trend } \\
\text { Test statistic }\end{array}$ \\
\hline $\begin{array}{l}\text { Levels } \\
\text { Log total population }\end{array}$ & $-4.9696 * * *$ & $-16.6893 * * *$ & 3.0758 & $-8.1085 * * *$ & 0.9521 & 0.7495 \\
\hline $\begin{array}{l}\text { Differences } \\
\Delta \log \text { total population }\end{array}$ & $-14.3234 * * *$ & $-8.8736 * * *$ & $-9.9758 * * *$ & $-2.9017 * * *$ & $0.4475 * * *$ & $0.7419 * * *$ \\
\hline
\end{tabular}

$(*, * *, * * *$ denote statistical significance at the 10\%-, 5\%- and 1\%-level, respectively)

Table A3. Panel cointegration tests (with total population)

\begin{tabular}{l|c|c|c|c|}
\multicolumn{4}{|c|}{ Specification } \\
Variables & {$[1]$} & {$[2]$} & {$[3]$} & {$[4]$} \\
\hline Log real house price & $\mathrm{x}$ & $\mathrm{x}$ & $\mathrm{x}$ & $\mathrm{x}$ \\
Log total population & $\mathrm{x}$ & $\mathrm{x}$ & $\mathrm{x}$ & $\mathrm{x}$ \\
Log old age dependency ratio & $\mathrm{x}$ & $\mathrm{x}$ & $\mathrm{x}$ & $\mathrm{x}$ \\
Log income per capita & $\mathrm{x}$ & $\mathrm{x}$ & $\mathrm{x}$ & $\mathrm{x}$ \\
Log human capital ratio & & & $\mathrm{x}$ & $\mathrm{x}$ \\
Log real mortgage interest rate & & $\mathrm{x}$ & & $\mathrm{x}$ \\
& & & & \\
Cointegration tests & & & & \\
\hline Kao ADF-statistic & & & & \\
Pedroni panel v-statistic & $\mathbf{1 . 6 8 7 9} * *$ & -1.8163 & 0.4713 & -2.9768 \\
Pedroni panel rho-statistic & 2.7446 & 5.4385 & 5.0553 & 7.2363 \\
Pedroni panel PP-statistik & $\mathbf{- 1 . 9 9 9 3} * *$ & $\mathbf{- 1 . 7 5 4 4} * *$ & $\mathbf{- 1 . 3 4 2 8} *$ & $\mathbf{- 2 . 8 1 9 7} * * *$ \\
Pedroni panel ADF-statistic & $\mathbf{- 1 . 5 1 0 3 *}$ & -0.1682 & -0.7108 & -0.0828 \\
Pedroni group rho-statistic & 5.9360 & 8.5958 & 8.3828 & 10.5682 \\
Pedroni group PP-statistic & $\mathbf{- 3 . 6 2 3 3} * * *$ & $\mathbf{- 4 . 7 8 8 3} * * *$ & $\mathbf{- 5 . 3 1 9 8 * * *}$ & $\mathbf{- 1 1 . 2 8 9 3 * * *}$ \\
Pedroni group ADF-statistic & $\mathbf{- 3 . 3 4 5 9} * * *$ & $\mathbf{- 2 . 2 7 5 5 * *}$ & $\mathbf{- 3 . 3 2 2 1} * * *$ & $\mathbf{- 3 . 1 7 8 7} * * *$
\end{tabular}

$(*, * *, * * *$ denote statistical significance at the 10\%-, 5\%- and 1\%-level, respectively)

${ }^{18}$ Data source of total population: German Federal Statistical Office. 
Table A4. Panel error correction models (with total population)

\begin{tabular}{|c|c|c|c|c|}
\hline \multirow[b]{2}{*}{ Pooled mean-group estimation } & \multicolumn{4}{|c|}{ Specification } \\
\hline & {$[1]$} & {$[2]$} & {$[3]$} & {$[4]$} \\
\hline Log total population & $0.6739 * * *$ & -0.0034 & 0.2217 & 0.2172 \\
\hline Log old age dependency ratio & $-0.9299 * * *$ & $-1.3148 * * *$ & $-1.4178 * * *$ & $-1.7757 * * *$ \\
\hline Log income per capita & $0.2515 * * *$ & $0.1530 * * *$ & 0.0718 & $0.1321 * *$ \\
\hline Log human capital ratio & & & $0.2157 * * *$ & $0.1101 * * *$ \\
\hline Log real mortgage interest rate & & $-0.1077 * * *$ & & $-0.1431 * * *$ \\
\hline Error correction term & $-0.3355 * * *$ & $-0.3075 * * *$ & $-0.3206 * * *$ & $-0.2845 * * *$ \\
\hline \multicolumn{5}{|l|}{ Mean-group estimation } \\
\hline Log total population & -7.9397 & 0.2125 & 2.6389 & 6.4633 \\
\hline Log old age dependency ratio & -1.0608 & $-1.5215 * * *$ & -0.7348 & $-2.2524 * * *$ \\
\hline Log income per capita & -2.3644 & 3.8148 & -0.3953 & 1.3166 \\
\hline Log human capital ratio & & & -0.3741 & -0.1770 \\
\hline Log real mortgage interest rate & & -0.0296 & & 0.0876 \\
\hline Error correction term & $-0.6431 * * *$ & $-0.6675 * * *$ & $-0.7309 * * *$ & $-0.8367 * * *$ \\
\hline \multicolumn{5}{|l|}{ Dynamic fixed-effects estimation } \\
\hline Log total population & $1.6799 * * *$ & $1.4248 * * *$ & $1.5531 * * *$ & $1.4055 * * *$ \\
\hline Log old age dependency ratio & $-1.1698 * * *$ & $-1.6619 * * *$ & $-1.3565 * * *$ & $-1.6883 * * *$ \\
\hline Log income per capita & $0.3631 * * *$ & $0.4172 * * *$ & $0.3992 * *$ & $0.4200 * * *$ \\
\hline Log human capital ratio & & & $0.1559 * * *$ & $-0.0085 * *$ \\
\hline Log real mortgage interest rate & & $-0.2370 * * *$ & & $-0.2444 * * *$ \\
\hline Error correction term & $-0.1616 * * *$ & $-0.1339 * * *$ & $-0.1470 * * *$ & $-0.1345 * * *$ \\
\hline
\end{tabular}

$(*, * *, * * *$ denote statistical significance at the $10 \%-, 5 \%-$ and $1 \%$-level, respectively) 
Table A5. Pooled OLS regression with all variables in first differences

\begin{tabular}{|c|c|c|c|c|}
\hline \multirow[b]{2}{*}{ Pooled OLS regression } & \multicolumn{4}{|c|}{ Specification } \\
\hline & {$[1]$} & {$[2]$} & {$[3]$} & {$[4]$} \\
\hline$\triangle$ Log total houshold population & 0.0379 & 0.0622 & 0.0377 & 0.0618 \\
\hline$\triangle$ Log old age dependency ratio & $-0.8495 * * *$ & $-0.7978 * * *$ & $-0.8481 * * *$ & $-0.7940 * * *$ \\
\hline$\triangle$ Log income per capita & 0.0401 & 0.0235 & 0.0405 & 0.0245 \\
\hline$\triangle$ Log human capital ratio & & & 0.0036 & 0.0089 \\
\hline$\Delta$ Log real mortgage interest rate & & $-0.0158 * * *$ & & $-0.0160 * * *$ \\
\hline Regression diagnostics & & & & \\
\hline $\mathrm{R}^{2}$ & 0.1127 & 0.1183 & 0.1128 & 0.1184 \\
\hline Adj. $R^{2}$ & 0.1109 & 0.1159 & 0.1103 & 0.1154 \\
\hline $\mathrm{AIC}(\mathrm{BIC})$ & $-4,970(-4,949)$ & $-4,968(-4,941)$ & $-4,968(-4,941)$ & $-4,975(-4,943)$ \\
\hline$\triangle$ Log total population & -0.2635 & -0.2195 & -0.2706 & -0.2297 \\
\hline$\Delta$ Log old age dependency ratio & $-0.8926 * * *$ & $-0.8379 * * *$ & $-0.8905 * * *$ & $-0.8341 * * *$ \\
\hline$\triangle$ Log income per capita & 0.3180 & 0.0168 & 0.0327 & 0.0180 \\
\hline$\Delta$ Log human capital ratio & & & 0.0084 & 0.0128 \\
\hline$\Delta$ Log real mortgage interest rate & & $-0.0150 * * *$ & & $-0.0152 * * *$ \\
\hline Regression diagnostics & & & & \\
\hline $\mathrm{R}^{2}$ & 0.1143 & 0.1193 & 0.1143 & 0.1195 \\
\hline Adj. $R^{2}$ & 0.1125 & 0.1169 & 0.1119 & 0.1165 \\
\hline $\mathrm{AIC}(\mathrm{BIC})$ & $-4973(-4952)$ & $-4979(-4952)$ & $-4971(-4944)$ & $-4977(-4946)$ \\
\hline
\end{tabular}

$(*, * *, * * *$ denote statistical significance at the $10 \%-, 5 \%-$ and $1 \%$-level, respectively) 